\title{
Environmental impact and biological removal processes of pharmaceutically active compounds: The particular case of sulfonamides, anticonvulsants and steroid estrogens
}

\author{
Cristiano S. Leal $\mathbb{D}^{a}$, Daniela P. Mesquita $\mathbb{D}^{\mathrm{a}}$, António Luís Amaral $\mathbb{D}^{\mathrm{a}, \mathrm{b}}$, \\ Almerinda M. Amaral ${ }^{c}$, and Eugénio C. Ferreira (D) ${ }^{a}$ \\ ${ }^{a}$ CEB - Centre of Biological Engineering, Universidade do Minho, Braga, Portugal; ${ }^{b}$ Instituto \\ Politécnico de Coimbra, ISEC, Departamento de Engenharia Química e Biológica, Coimbra, \\ Portugal; 'Farmácia Moderna, Viana do Castelo, Portugal
}

\begin{abstract}
Pharmaceutically active compounds (PhACs) have recently received wide attention in the scientific community due to their extensive consumption for human health and consequent discharge to the environment. Release of PhACs into the environment, even in trace amounts, can cause serious environmental damage. This has become a major concern and their removal from water sources is a priority. Although a few PhACs are efficiently removed in wastewater treatment plants (WWTPs), others remain recalcitrant, and their release is causing damage. In this review, the current state of the art on the biological removal processes of sulfonamide sulfamethoxazole (SMX), the anticonvulsant carbamazepine (CBZ), and steroid estrogens $17 \beta$-estradiol (E2) and $17 \alpha$-ethinylestradiol (EE2) are discussed, along with their environmental impact. Other systems beyond activated sludge, such as membrane bioreactors, enzymatic membrane reactors, fungi treatments and hybrid systems are also becoming of major interest and are being evaluated for the removal of these compounds. Future perspectives are addressed.
\end{abstract}

\section{KEYWORDS}

Pharmaceutically Active Compounds (PhACs); sulfamethoxazole; carbamazepine; $17 \beta$-estradiol; $17 \alpha$-ethinylestradiol; biological wastewater treatment systems

\section{Introduction}

PhACs are an emerging concern worldwide. The European Union (EU) is the second biggest consumer in the World, with $24 \%$ of the total consumption, just a little less than the United States of America. Consumption per capita in EU ranges from 50 to $150 \mathrm{~g} \mathrm{year}^{-1}$ for human medical products (Mugdal et al., 2013). About 4000 PhACs are used around the World for many purposes, with production rates reaching up to 100,000 tons year ${ }^{-1}$ for a number of them (IWW, 2014).

CONTACT Daniela P. Mesquita daniela@deb.uminho.pt E CEB - Centre of Biological Engineering, Universidade do Minho, Campus de Gualtar, Braga, 4710-057, Portugal.

Color versions of one or more of the figures in the article can be found online at www.tandfonline.com/best. 
Regarding the particular case of the anticonvulsant, carbamazepine (CBZ), the world's annual consumption is estimated at 1,014 tons (Zhang, Geißen, \& Gal, 2008). With respect to the total amount of discharged natural steroid estrogens (estrone - E1, estriol - E2 and 17 $\beta$-estradiol - E3), it is estimated in 29.5 tons year ${ }^{-1}$ (considering the world's population of 6.7 billion inhabitants). Moreover, $720 \mathrm{~kg}$ year $^{-1}$ of synthetic estrogens (17 $\alpha$-ethinylestradiol - EE2) are also released solely by contraceptive pills used (Combalbert \& HernandezRaquet, 2010). Antibiotics consumption increased 65\% between 2000 and 2015, from 21.1 to 34.8 billion daily doses (DDDs) and the consumption rate also increased $39 \%$ (from 11.3 to 13.7 DDDs inhabitant ${ }^{-1}$ day $^{-1}$; Klein et al., 2018). The total amount of antibiotics is estimated between 100,000 and 200,000 ton year $^{-1}$ with approximatively $50 \%$ used for veterinary medicine and as growth promoters (Kümmerer, 2003; Danner, Robertson, Behrends, \& Reiss, 2019), sulfonamides being one of the most commonly used for veterinary purposes (Sarmah, Meyer, \& Boxall, 2006a).

\subsection{PhACs in wastewaters}

PhACs are commonly present in domestic sewages largely because of human excretion. Indeed, some of these compounds are not completely metabolized during their therapeutic use and are excreted unchanged (Mohapatra, Brar, Tyagi, Picard, \& Surampalli, 2014). PhACs are nowadays considered as an emerging environmental problem due to their continuous release into and persistence in the aquatic ecosystem, even at low concentrations (Carabin, Drogui, \& Robert, 2015). Concern about this release in recent decades is growing; the extent of their effects remains relatively unknown, due to lack of standard methods of quantification. This is considered a major challenge in water resources management (Geissen et al., 2015).

The interest of studying PhACs in full-scale wastewater treatment plants (WWTPs) has been increasing over the last decades, mainly due to the large amounts of PhACs that can be present. Although some of these compounds can mostly be removed, a few cannot, causing a number of serious environmental and human health problems due to their recalcitrance. In this sense, sulfonamide antibiotics, anticonvulsants, and steroid estrogens are 3 major $\mathrm{PhACs}$ classes of particular interest and concern due to their extensive use in human health.

\subsection{PhACs metabolism in the human body}

The most common antibiotics found in WWTPs cover a wide range of classes, such as $\beta$-lactams, quinolones, lincosamides, macrolides, tetracyclines, polyether ionophores, polypeptides, sulfonamides and others (Watkinson, 
Murby, \& Costanzo, 2007). The sulfonamide sulfamethoxazole (SMX) is widely applied as a broad-spectrum bacteriostatic drug because it interferes with folic acid synthesis in susceptible bacteria. SMX is used all over the world for the treatment of bronchitis, prostatitis and urinary tract infections (Lipman, 1993; Cavallucci, 2007). It should also be stressed that SMX is usually used in combination with trimethoprim for increased reduction of tetrahydrofolic acid synthesis (Drugbank, 2016b). The mechanism of action of SMX involves the inhibition of the bacterial synthesis of dihydrofolic acid, thus decreasing the synthesis of bacterial nucleotides and DNA. It inhibits the enzymatic conversion of pteridine and p-aminobenzoic acid (PABA) to dihydropteroic acid by competing with PABA for binding to dihydrofolate synthetase. As a result, it inhibits the tetrahydrofolic acid synthesis required for purines and deoxythymidine monophosphate (dTMP) synthesis, thus affecting bacterial growth.

The metabolism of SMX in the human body is largely hepatic and occurs predominately by N4-acetylation (N4-acetyl-SMX), although glucorination (SMX-N1-Glu, SMX-2-Glu) also occurs (Drugbank, 2016b). Significant amounts (45-75\%) of ingested sulfonamides are excreted by the human body within $24 \mathrm{~h}$, thus entering WWTPs through the sewage systems and being found in surface waters (Calamari, Zuccato, Castiglioni, Bagnati, \& Fanelli, 2003; Radke, Lauwigi, Heinkele, MüRdter, \& Letzel, 2009). Regarding the specific case of SMX, it should be stressed also that 15 to $30 \%$ is excreted unaltered from humans (Hirsch, Ternes, Haberer, \& Kratz, 1999, RxList, 2016b).

Anticonvulsants are a class of PhACs that act by reducing abnormal activity in the brain, and are applied in the treatment of mental illnesses, depression, post-traumatic stress disorders, and drug and alcohol dependencies, among others (Mohapatra et al., 2014). One of the most frequently detected anticonvulsant in water bodies is carbamazepine (CBZ) (Zhang et al., 2008), usually employed in the treatment of epilepsy, seizures, trigeminal neuralgia, diabetic neuropathy, bipolar disorder, and drug and alcohol dependencies, among others (RxList, 2016a; Drugbank, 2016a). The mechanism of action of CBZ involves inhibiting sustained repetitive firing by blocking use-dependent sodium channels, norepinephrine release, synaptic transmission in the trigeminal nucleus, and reduction of post-tetanic potentiation on the spinal cord synaptic transmission. It is also believed to possess anticholinergic, antidiuretic, antiarrhythmic, and antidepressant activity, thus acting as a muscle relaxant and sedative (Drugbank, 2016a).

The metabolism of CBZ in the human body leads to the formation of 10,11-epoxycarbamazepine (EP-CBZ) and 10,11-dihydro-10,11-trans-dihydroxycarbamazepine (DiOH-CBZ). The CBZ is transformed by the cytochrome P450 3A4 (CYP3A4) in the liver and possibly undergoes 
glucuronidation by UDP-glucuronosyltransferase-2B7 (UGT2B7) isoenzyme. Only 3\% of CBZ remains unchanged when excreted, and is mainly found in the urine, whereas their (mono)hydroxylated and conjugated metabolites can be found in the feces (RxList, 2016a; INCHEM, 2016; Toxnet, 2016).

Steroid hormones are a group of biologically active compounds synthesized from cholesterol and with a common cyclopentane-perhydro phenanthrene ring (Ying, Kookana, \& Ru, 2002). Four of the estrogens most commonly found in wastewater include 3 natural steroids (17 $\beta$-estradiol (E2), estrone (E1) and estriol (E3)) and one synthetic compound (17 $\alpha$-ethinylestradiol (EE2)) (Racz \& Goel, 2010). E2 is a naturally occurring steroid hormone, being the major female sex hormone, and is essential factor in the regulation of the menstrual cycle, in the development of puberty and in secondary female sex characteristics. E2 can also be present in hormone therapy products, such as reduced estrogen production (menopausal and peri-menopausal symptoms), treatment of hypoestrogenism, palliative treatment of breast and prostate cancer, as well as for transgender hormone therapy (Drugbank, 2016c). EE2 is used mainly for the treatment of vasomotor symptoms associated with the menopause, female hypogonadism, prostatic carcinoma-palliative therapy, treatment of breast cancer, and contraceptive purposes (Drugbank, 2016d).

The mechanism of action of estrogens is based on the interaction with a protein receptor on the cells of the female reproductive tract, mammary glands, hypothalamus and pituitary gland. This leads to an increased synthesis of sex hormones binding globulins in the liver, thyroid-binding globulins and serum proteins, as well as the suppression of the folliclestimulating hormone. Metabolism of estrogens in the human body is largely hepatic, mainly by aromatic hydroxylation (for both synthetic and natural estrogens); for instance, E2 is excreted in the urine along with glucuronide and sulfate conjugates. While glucuronide conjugates can be mostly removed, or transformed back to the original compounds, sulfate conjugates are likely found in treated wastewaters due their lower deconjugation rates.

With respect to the toxicity of E2 conjugates, more studies are needed to confirm the effect of these compounds in aquatic organisms (Drugbank, 2016c; Liu, Lu, Yin, Dang, \& Rittmann, 2015, Zhang, Zhao, \& Fent, 2017). E2 is one of 3 naturally occurring steroid estrogens produced by the human body. Females excrete on average more E2 than males (2.9 and $1.6 \mu \mathrm{g}$ day $^{-1}$, respectively), with menstruating $\left(3.5 \mu \mathrm{g}_{\text {day }}{ }^{-1}\right)$ and pregnant $(259 \mu \mathrm{g}$ day $^{-1}$ ) women excreting particularly large amounts of this natural estrogenic compound (Johnson, Belfroid, \& Di Corcia, 2000; Wise, O’Brien, \& Woodruff, 2011). Regarding EE2, the main metabolite is 2-hydroxy- 
ethinylestradiol, but a number of other hydroxylated and methoxylated metabolites can also be found in the free form or as sulfates and conjugated glucuronides (Drugbank, 2016d). The major source of EE2 excretion is urine, in contrast with feces where large E. coli populations are able to deconjugate EE2 metabolites due to their $\beta$-glucuronidase and sulfatase activities (Dray, Dray, \& Ullmann, 1972; Desbrow, Routledge, Brighty, Sumpter, \& Waldock, 1998).

This review outlines the importance, strategies, and efficiency of the removal processes of the sulfonamide SMX, the anticonvulsant CBZ, and the estrogens E2 and EE2 in biological wastewater treatment (WWT) systems. With the concerns discussed above, accordingly SMX, CBZ, E2 and EE2 have in particular been addressed in this review, covering the main sources of these PhACs, and their impacts in soils, surface waters, aquatic biota and human health. Furthermore, the impact of PhACs on microbial communities in the WWTPs is far from negligible and, for that reason, this topic will be also discussed.

Several studies have already shown that conventional activated sludge (CAS) treatment in WWTPs is inefficient for the removal of a large number of PhACs (Hirsch et al., 1999; Joss et al. 2006). Based on this information, different technologies have been studied and applied to obtain a sustainable removal of PhACs, including membrane reactors (MBR), enzymatic membrane reactors (EMR) and hybrid systems (HS), among others (Salgado et al., 2012; Mohapatra et al., 2014; Petrie, Barden, \& Kasprzyk-Hordern., 2015; Grandclément et al., 2017; Tiwari et al., 2017; Besha et al., 2017; Ahmed et al., 2017). Although knowledge of the relationship between the WWTPs operational conditions and the removal efficiencies of PhACs has been increasing, further information on the cost-benefit aspects of these technologies are of major interest to achieve full-scale implementation. Therefore, we will also be discussed herein the future perspectives and challenges regarding the sustainable removal of these compounds.

\section{Sources and environmental impact assessment of PhACs}

SMX, CBZ, E2 and EE2 can flow into WWTPs from hospital activities, clinical analysis laboratories and industrial activities such as pills production in the pharmaceutical industry (Cui, Ji, \& Ren, 2006; Avberšek, Šömen, \& Heath, 2011; Zhou, Zha, Xu, Lei, \& Wang, 2012). Moreover, the surface waters distributed to the urban environment, even when treated in water treatment plants (WTP), may contain considerable amounts of these PhACs (Ting \& Praveena, 2017), which later contaminate soils and aquifers. Figure 1 shows the main sources of SMX, CBZ, E2 and EE2 flowing into a WWTP, as well as the dissemination of these compounds in different 


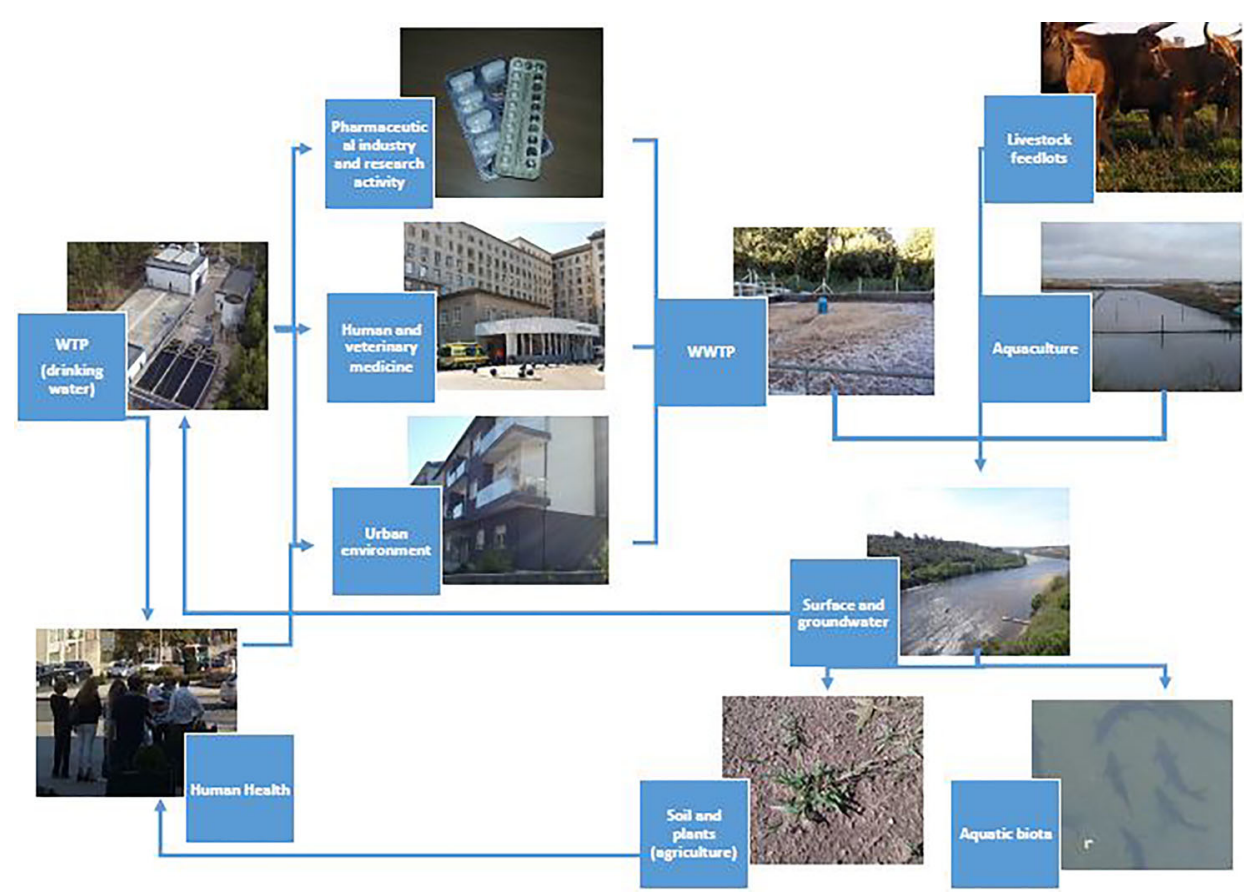

Figure 1. SMX, CBZ, E2 and EE2 in different environmental compartments (Ting \& Praveena, 2017).

environmental compartments, including water, wastewater, soils and aquatic biota.

PhACs are been commonly found in ground waters, surface waters, treated wastewaters, and even drinking waters, in concentrations up to tens of nanograms per liter for E2, hundreds of nanograms per liter regarding SMX, up to $1 \mathrm{mg} \mathrm{L}^{-1}$ for EE2, and even $>1 \mathrm{mg} \mathrm{L}^{-1}$ for CBZ. The concentrations SMX, CBZ, E2 and EE2 in aquatic systems reported by others are given in Table 1. Furthermore, a wide variety of $\mathrm{PhAC}$ conjugated metabolites may undergo deconjugation in the environment, being transformed back to their original forms (Celiz, Tso, \& Aga, 2009).

The ecotoxicity of PhACs is usually assessed by means of the Lowest Observed Effect Concentration (LOEC) and Predicted No-Effect Concentration (PNEC). Table 2 gives further information about the PNEC and the LOEC for the toxicity assessment of SMX, CBZ, E2 and EE2. CBZ had LOEC values ranging from hundreds of micrograms per liter in arthropods and rotifers and up to tens of milligrams per liter in fish (Ferrari, Paxéus, Lo Giudice, Pollio, \& Garric, 2003). With respect to the PNEC, values as low as a few nanograms per liter for E2 (Anderson et al., 2012), and even lower for EE2 (Laurenson, Bloom, Page, \& Sadrieh, 2014), were found in aquatic life. Ma and Yates (2018) found that 17ß-estradiol-3-sulfate (E2$3 \mathrm{~S})$ conjugate is more persistent in rivers and streams than 17ß-estradiol-3glucuronide (E2-3G) conjugate. However, since the ecotoxicity of these 
Table 1. Concentrations of SMX, CBZ, E2 and EE2 in aquatic systems.

\begin{tabular}{|c|c|c|c|}
\hline Compound & Concentration & Type of water & References \\
\hline \multirow[t]{3}{*}{$\overline{S M X}$} & Around $410 \mathrm{ng} \mathrm{L}^{-1}$ & Ground water & $\begin{array}{l}\text { Sacher, Lange, Brauch, } \\
\text { and Blankenhorn (2001) }\end{array}$ \\
\hline & Around $480 \mathrm{ng} \mathrm{L}^{-1}$ & Surface water & Hirsch et al. (1999) \\
\hline & Around $66 \mathrm{ng} \mathrm{L}^{-1}$ & Drinking water & Mückter (2006) \\
\hline \multirow[t]{8}{*}{$\mathrm{CBZ}$} & $390 \mathrm{ng} \mathrm{L}^{-1}$ (max) & Ground water & Loos et al. (2010) \\
\hline & Above $1 \mu \mathrm{g} \mathrm{L}^{-1}$ & Surface water & Wiegel et al. (2004) \\
\hline & $0.060 \mu \mathrm{g} \mathrm{L}^{-1}$ & & Thill (2005) \\
\hline & $1075 \mathrm{ng} \mathrm{L}^{-1}$ & & Heberer et al. (2002) \\
\hline & $0.650 \mathrm{ng} \mathrm{L}^{-1}(\max )$ & & Metcalfe et al. (2003b) \\
\hline & $30 \mathrm{ng} \mathrm{L}^{-1}$ & Drinking water & Ternes (1998) \\
\hline & $6.3 \mathrm{mg} \mathrm{L}^{-1}$ & WWTPs effluents & Ternes (1998) \\
\hline & $2.3 \mu \mathrm{g} \mathrm{L}^{-1}(\max )$ & Discharged wastewater & Metcalfe et al. (2003) \\
\hline \multirow[t]{2}{*}{ E2 } & 1 to $22 \mathrm{ng} \mathrm{L}^{-1}$ & WWTPs & Pal, Gin, Lin, and Reinhard (2010) \\
\hline & 0 to $4.5 \mathrm{ng} \mathrm{L}^{-1}$ & River streams & Pal et al. (2010) \\
\hline \multirow[t]{2}{*}{ EE2 } & 0 to $9 \mu \mathrm{g} \mathrm{L}^{-1}$ & Treated wastewater & Baronti et al. (2000) \\
\hline & $\begin{array}{c}831 \mu \mathrm{g} \mathrm{L}^{-1} \text { (max.) and } \\
73 \mu \mathrm{g} \mathrm{L}^{-1} \text { (avg.) }\end{array}$ & Stream water & Kolpin et al. (2002) \\
\hline
\end{tabular}

Table 2. PNEC and LOEC regarding SMX, CBZ, E2, and EE2 toxicity assessment.

\begin{tabular}{|c|c|c|c|}
\hline Compound & LOEC & PNEC & References \\
\hline \multirow[t]{3}{*}{ SMX } & n.a & $0.59 \mu \mathrm{g} \mathrm{L}^{-1}$ for aquatic life & Straub (2016) \\
\hline & n.a & $0.89 \mu \mathrm{g} \mathrm{L}^{-1}$ for aquatic life & Huang et al. (2018) \\
\hline & $\begin{array}{l}1.97 \mathrm{nmol} \mathrm{L}^{-1} \text { for river } \\
\text { biofilms communities }\end{array}$ & n.a & $\begin{array}{l}\text { Yergeau, Lawrence, Waiser, } \\
\text { Korber, and Greer (2010); } \\
\text { Yergeau et al. (2012) }\end{array}$ \\
\hline Avetyl-SMX & n.a & $\begin{array}{l}28 \mathrm{ng} \mathrm{L}^{-1} \text { for Vidu bay } \\
\text { in lake Geneva }\end{array}$ & $\begin{array}{l}\text { Bonvin, Chevre, Rutler, } \\
\text { and Kohn (2012) }\end{array}$ \\
\hline SMX-Glu & n.a & $\begin{array}{l}28 \mathrm{ng} \mathrm{L}^{-1} \text { for Vidu bay } \\
\text { in lake Geneva }\end{array}$ & Bonvin et al. (2012) \\
\hline \multirow[t]{2}{*}{$\mathrm{CBZ}$} & $\begin{array}{l}100 \mu \mathrm{g} \mathrm{L}^{-1}, 754 \mu \mathrm{g} \mathrm{L}^{-1} \\
\text { and } 50 \mathrm{mg} \mathrm{L}^{-1} \text { for } \\
\text { C. dubia, B. calyciflorus and } \\
\text { D. rerio respectively }\end{array}$ & n.a & Ferrari et al. (2003) \\
\hline & n.a & $6.359 \mu \mathrm{g} \mathrm{L}^{-1}$ for daphnids & $\begin{array}{l}\text { Jones, Voulvoulis, } \\
\text { and Lester (2002) }\end{array}$ \\
\hline EP-CBZ & n.a & $\begin{array}{l}2500 \mathrm{ng} \mathrm{L}^{-1} \text { for Vidu bay } \\
\text { in lake Geneva }\end{array}$ & Bonvin et al. (2012) \\
\hline DiOH-CBZ & n.a & $\begin{array}{l}2500 \mathrm{ng} \mathrm{L}^{-1} \text { for Vidu bay } \\
\text { in lake Geneva }\end{array}$ & Bonvin et al. (2012) \\
\hline Acridone & $\begin{array}{l}1.44-3.07 \mathrm{mg} \mathrm{L}^{-1} \text { and } \\
1.09 \mathrm{mg} \mathrm{L}^{-1} \text { for } \mathrm{V} \text {. fischeri } \\
\text { and } P \text {. subcapitata } \\
\text { respectively }\end{array}$ & n.a & Donner et al. (2013) \\
\hline \multirow[t]{4}{*}{ E2 } & n.a & $5 \mathrm{ng} \mathrm{L}^{-1}$ (short term on fish) & Anderson et al. (2012) \\
\hline & & $2 \mathrm{ng} \mathrm{L}^{-1}$ (long term on fish) & Anderson et al. (2012) \\
\hline & $\begin{array}{l}\text { Below } 8.94 \mathrm{ng} \mathrm{L}^{-1} \text {, below } \\
28.8 \mathrm{ng} \mathrm{L}^{-1} \text { and below } \\
85.9 \mathrm{ng} \mathrm{L}^{-1} \text { for medaka, } \\
\text { fathead minnow, and } \\
\text { zebrafish respectively }\end{array}$ & n.a & $\begin{array}{l}\text { Seki, Fujishima, Nozaka, } \\
\text { Maeda, and Kobayashi (2006) }\end{array}$ \\
\hline & n.a & $2 \mathrm{ng} \mathrm{L}^{-1}$ & $\begin{array}{l}\text { Caldwell, Mastrocco, Anderson, } \\
\text { Lange, and Sumpter (2012) }\end{array}$ \\
\hline \multirow[t]{2}{*}{ EE2 } & n.a & $0.1 \mathrm{ng} \mathrm{L}^{-1}$ for aquatic life & $\begin{array}{l}\text { Pawlowski, Van Aerle, Tyler, } \\
\text { and Braunbeck (2004); } \\
\text { Laurenson et al. (2014) }\end{array}$ \\
\hline & $1 \mathrm{ng} \mathrm{L}^{-1}$ for fathead minnow & n.a & Pawlowski et al. (2004) \\
\hline
\end{tabular}

n.a - Not available 
compounds remains unknown, further studies are needed. SMX also has low PNEC values, $<1$ microgram per liter, for aquatic life (Straub, 2016). However, the toxicity values of PhACs reported in the literature should be carefully analyzed since the results are strongly dependent on the species involved, and whether in vitro or in vivo assays are used (Laurenson et al., 2014).

\subsection{Sulfonamides}

Sulfonamides, including SMX, are widely prescribed and used to treat animals and humans all over the world with its acetylated and conjugated compounds posing an environmental risk (Hruska \& Franek, 2012). Although Andreozzi, Raffaele, and Nicklas (2003) report that direct and indirect photodegradation can be an important process for the elimination of SMX, these compounds are only partially degraded in the environment; as a result, they are likely to accumulate in water bodies such as ground waters, surface waters and drinking waters in amounts up to hundreds of nanograms per liter (Table 1). On the other hand, acetylsulfamethoxazole, a SMX metabolite that may be transformed back to the parent form, has been detected at concentrations approaching $100 \mathrm{ng} \mathrm{L}^{-1}$ in WWTPs effluents and river streams (Göbel, McArdell, Suter, \& Giger, 2004; Ashton, Hilton, \& Thomas, 2004). Moreover, the concentrations of these antibiotics in WWTPs varies according to the consumption patterns, as well as the treatment methodology (Michael et al., 2013).

The effects of SMX in aquatic life remains poorly understood, and lacks information of the potential consequences of this antibiotic in the environment due to waste water discharge or reuse (Watkinson et al., 2007). Lin, Chen, and Chen (2013) showed the toxic effects of sulfonamides (including SMX), even at low concentrations, on the spontaneous movements, heartbeats and malfunctions of zebra fish embryos and larvae. SMX exposure can also lead to changes on the zebra fish liver (Madureira et al., 2012). Exposure of zebra fish to sulfonamides (including SMX) has also been related to pericardial edema, York sac edema hemagglutination, tail deformation and swim-bladder defects (Lin et al., 2013). SMX and SMXtransformation products (SMX-TP) resulting from the SMX biodegradation, photolysis or hydrolysis in the aquatic environment can also have acute effects on Vibrio fischeri, leading to inhibition of luminescence. However, the effects of SMX-TP seem to be lower than their parent compound (Majewsky et al., 2014). On the other hand, Osorio et al. (2016) showed that SMX had no individual acute toxicity on $V$. fischeri and Daphnia magna (using standardized acute toxicity tests), although synergic effects were determined with Diclofenac and nitro Diclofenac derivatives. However, 
the mechanism behind these effects is poorly understood. Bisphenol A, humic acid and E2 also have a synergistic interaction with SMX leading to an increase of estrogenicity in water bodies by up to 5-fold (Ali, 2014).

The long-term persistence of antibiotics (at low concentrations) in the environment can promote the proliferation of antibiotic resistant bacteria in river streams and, thus stimulate microorganism drug resistance (Martinez, 2008; Watkinson, Murby, Kolpin, \& Costanzo, 2009). Detection of sulfonamide resistance genes in river microorganisms and aquatic biofilm communities (Luo et al., 2010; Koczura, Mokracka, Taraszewska, \& Lopacinska, 2016; Aubertheau et al., 2017), alongside the prevalence of SMX-resistant bacteria in aquaculture environments (Gao et al., 2012), have been correlated to the total SMX concentration, among other sulfonamides, in those environments. On the other hand, some investigations have shown that the bacterial resistance develops more slowly when trimethoprim and sulfamethoxazole are combined rather than when they are used alone (Drugbank, 2016b; Vilchèze \& Jacobs, 2012). The fact that TMP and SMX target successive steps of the folate biosynthesis pathway can be the reason for this behavior. Whereas SMX inhibits dihydropteroate synthase TMP targets dihydrofolate reductase in the bacterial de novo folate synthesis pathway (Vilchèze \& Jacobs, 2012).

Besides their impact in aquatic biota, SMX, among others sulfonamides, were also found in soil (Wang et al., 2015), with their sorption behavior being related to soil properties, such as the presence of manure or organic carbon source, and to the $\mathrm{pH}$. In agricultural runoff waters resulting from biosolids introduction in soils, SMX deconjugation can also lead to increased concentrations of the SMX parent form with time (Topp et al., 2008). Another important issue that is closely related to the presence of SMX in soils is the effect of this compound in their microbial community. In this sense, Demoling, Bååth, Greve, Wouterse, and Schmitt (2009) showed that SMX initially decreased growth rates of sensitive bacterial species in the soil (assessed by leucine incorporation). SMX showed also an apparent correlation with the soil microbial diversity, measured by the Shannon-Winner index, the Pielou's evenness index and Simpson's index of diversity (Wang et al., 2016). Simpson's index of diversity indicates the probability of 2 individuals from an infinitely large community belonging to the same species, with higher values showing the predominance of fewer species, and consequently lower biodiversity. The Shannon-Winner index increases with biodiversity, attributing a higher importance to rare than to common species (Magurran, 2004).

Different SMX effects in soil-plant systems have already been detected, for instance their higher rate accumulation in radish than in packoi cultures, and an apparent correlation with seed germination and up-ground 
plant growth (Wang et al., 2016). According to Liu et al. (2009), root elongation was sensitive to SMX (and sulfamethazine) during plant germination and growth. These antibiotics also inhibited soil phosphatase activity, as well as affecting temporal changes on soil respiration. However, these authors also considered that the expected effects regarding plant growth and soil microbial activities may be mild, and show a quick recovery due to loss and/or binding of SMX on to soil components. On the other hand, Brain, Ramirez, Fulton, Chambliss, and Brooks (2008) showed that SMX could disrupt the synthesis of folate and the substrate of dihydropteroate synthase in Lemma giba, using p-aminobenzoic acid as a biomarker. Due to its properties, SMX dissolves in cell membranes and is released into the cytosol in plants (Goldstein, Shenker, \& Chefetz, 2014). More recently, Christou et al. (2019) has proved that tomatoes can uptake and accumulate SMX in hydroponic conditions, increasing their carbohydrate content. However, different results were obtained by $\mathrm{Wu}$, Conkle, Ernst, and Gan (2014), who did not detect SMX in plant tissues, or in fields irrigated with treated wastewater. Despite the amount of information in the literature, further research is needed to address the effects of SMX in plants.

Regarding human health as a result of chronic exposure to environmental antibiotics, Hamscher, Pawelzick, Sczesny, Nau, and Hartung (2003) have stresed that a large number of antibiotics can give rise to allergic risks. Indeed, with respect to sulfonamides, a number of investigations have reported these allergic effects of sulfamethazine (Hjorth \& Roed-Petersen, 1980; Choquet-Kastylevsky, Vial, \& Descotes, 2002). Although no SMX effects alone have been thoroughly reported, Pomati et al. (2006) refer to the inhibition of human embryonic kidney cells at concentrations of nanograms per liter for a mixture of antibiotics containing sulfamethoxazole. On the other hand, Straub (2016) stated that no risk is apparent for indirect human exposure to SMX through drinking water and food, whereas Uslu, Jasim, Arvai, Bewtra, and Biswas (2013) came to the same conclusion regarding water bodies. However, this is not the case for sulfamethazine, which has the potential to increase thyroid gland follicular adenoma (Leung et al., 2013).

\subsection{Anticonvulsants}

As already mentioned, CBZ is widely applied as an anticonvulsant in epilepsy and in the treatment of drug and alcohol dependencies, among others applications. In the environment, $\mathrm{CBZ}$ can undergo a slow process of photodegradation (estimated half-life $\sim 100$ days) in waters free of salt and organic compounds (Andreozzi et al., 2003). In WWTPs, the photolysis step of UV treatment can also lead to a mixture of different carbamazepine 
transformation products, such as acridine and acridone (Donner et al., 2013); however, biotransformation has been recognized as the main elimination mechanism of $\mathrm{CBZ}$, though retransformation from its conjugated metabolites can impair this process (Polesel, Andersen, Trapp, \& Plósz, 2016).

Several studies have shown that conventional biological WWT systems are ineffective in removing CBZ (Bahlmann, Weller, Panne, \& Schneider, 2009; Bahlmann, Brack, Schneider, \& Krauss, 2014; Kruglova et al., 2014); for this reason, $\mathrm{CBZ}$ is the most common PhAC found in aquatic systems, including surface and ground waters (Clara, Strenn, \& Kreuzinger, 2004) (Table 1). In fact, according to Ternes (1998) and Heberer, Reddersen, and Mechlinski (2002), CBZ has been detected at up to $6.3 \mathrm{mg} \mathrm{L}^{-1}$ in WWTPs effluents (Ternes, 1998), above $1 \mu \mathrm{g} \mathrm{L}^{-1}$ in surface waters (Wiegel et al., 2004), up to $390 \mathrm{ng} \mathrm{L}^{-1}$ in ground waters (Loos et al., 2010) and up to $30 \mathrm{ng} \mathrm{L}^{-1}$ in drinking waters (Ternes, 1998). On the other hand, metabolites such as EP-CBZ, carbamazepine-10,11-dihydrodiol, 2-hydroxycarbamazepine and 3-hydroxycarbamazepine can be present in concentrations

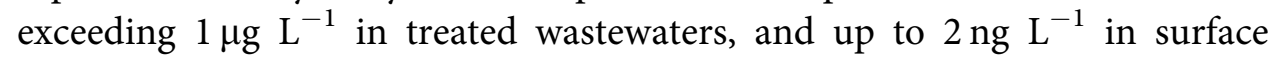
waters (Miao \& Metcalfe, 2003).

CBZ can be potentially harmful, even toxic, to aquatic life at concentrations below $100 \mathrm{mg} \mathrm{L}^{-1}$. However, toxicity levels are quite dependent on the test organisms (Fent, Weston, \& Caminada, 2006). Assessment of the ecotoxicological impact of CBZ in aquatic biota showed decreases in $D$. magna mobility and $V$. fischeri bioluminescence (Jos et al., 2003). Moreover, Allium cepa and Chlorella vulgaris have been affected by CBZ exposure (at up to $1000 \mu \mathrm{mol} \mathrm{L} \mathrm{L}^{-1}$ of CBZ), with their growth decreasing with contact time and CBZ concentration (Jos et al., 2003). Similar results have also been found by others regarding the CBZ toxic effect in fish liver tissue (Madureira et al., 2012) and in embryos. van den Brandhof and Montforts (2010) showed a clear negative effect on Danio rerio growth at concentrations $>30.6 \mathrm{mg} \mathrm{L}^{-1}$.

Regarding the ecotoxicity of CBZ's main metabolites, EP-CBZ was significantly more toxic ( $\mathrm{LC}_{50}$ of $0.20 \mathrm{mg} \mathrm{Kg}^{-1}$ ) to Chironomus riparius than CBZ ( $\mathrm{LC}_{50}$ of $1.20 \mathrm{mg} \mathrm{Kg}^{-1}$ ), assessed by the 40 -day sediment full life-cycle test. With respect to the EP-CBZ metabolite and its transformation products, fetal malformations in mice have also been described (Bennett et al., 1996). In addition, the decrease of $V$. fischeri bioluminescence, the inhibition of Pseudokirchneriella subcapitata growth and the decrease of $D$. magna mobility have also been reported for acridine and acridone, resulting from the photolysis step of UV treatment (Donner et al., 2013). On the contrary, no toxic effects have been reported so far for $\mathrm{DiOH}-\mathrm{CBZ}$ (Heye et al., 2016). 
Bioassays of ecotoxicity have also run on bacteria, algae, microcrustaceans and fish to estimate their PNEC and assess risk. Ferrari et al., (2003) concluded that CBZ seems to be more hazardous than the other PhACs, which is further emphasized considering that $\mathrm{CBZ}$ was the sole PhAC appearing in all of the WWTPs that were examined.

Regarding chronic effects, most of the data so far refers to those of CBZ on the hormonal and nervous systems in lower vertebrates and invertebrates (Ferrari et al., 2003; Thill, 2005). Others have shown that chronic effects (lasting over generations), as well as synergic effects with other chemicals, cannot be excluded (Jos et al., 2003; Lamichhane, Garcia, Huggett, Deangelis, \& La Point, 2013). In fact, Ferrari et al. (2003) determined a LOEC of $100 \mu \mathrm{g} \mathrm{\textrm {L } ^ { - 1 }}$ for Ceriodaphnia dubia, $754 \mu \mathrm{g} \mathrm{L}^{-1}$ for Brachionus calyciflorus and $50 \mathrm{mg} \mathrm{L}^{-1}$ for D. rerio. Indeed, WWTPs discharges containing $\mathrm{CBZ}$ can have a profound effect on aquatic biofilms communities through fixation of this compound (Aubertheau et al., 2017). Furthermore, several effects can occur (even over generations) when CBZ is released into the environment, including fixation in sediments and profound effects in insects (such as Chironomids) affecting food webs. In this sense, life-cycle tests are quite fundamental in minimizing CBZ risks to the environment (Nentwig, Oetken, \& Oehlmann, 2004).

$\mathrm{CBZ}$ is also one of the most studied PhACs in soils, with many researches trying to understand its behavior (including the interactions with organic materials) in several types of soils (Stein, Ramil, Fink, Sander, \& Ternes, 2008; Navon, Hernandez-Ruiz, Chorover, \& Chefetz, 2011; Fenet et al., 2012; Foolad, Hu, Tran, \& Ong, 2016; Paz et al., 2016). CBZ has a lower sorption affinity and a higher diffusion in soils compared to the parent compounds, EP-CBZ and DiOH-CBZ, and it can be easily transported from soil surfaces to aquifers (Paz et al., 2016). In fact, similar results were obtained when treated wastewater was used for the irrigation of soils and recharging of artificial aquifers (Fenet et al., 2012).

Regarding the effect of the chronic exposure to CBZ in water and food products on the human health, Uslu et al. (2013), among others, have suggested no apparent risks regarding the concentrations of CBZ found in these sources. On the other hand, the 2-hydroxycarbamazepine metabolite may lead to the formation of 2-hydroxyiminostilbene, and later to iminoquinone, which, ultimately, can be responsible for carbamazepine-mediated adverse drug reactions in humans (Ju \& Uetrecht, 1999).

\subsection{Steroid estrogens}

Estrogens present in the environment in concentrations up to hundreds of micrograms per liter can have a large impact on human and animal health 
(Stumpe \& Marschner, 2007). Since human excretion is a major source of the estrogens found in domestic wastewaters, the amount of estrogens, and namely EE2, depends of several factors, including gender, hormonal and menstrual state, pregnancy and contraceptive use (Johnson \& Sumpter, 2001).

WWTPs effluents could be seen as one of the major sources of E2 and EE2 in surface and ground waters (Table 1) due to its inefficient removal (Braga, Smythe, Schäfer, \& Feitz, 2005), alongside livestock manure and aquaculture (Sarmah, Meyer, et al., 2006b; Kolodziej, Harter, \& Sedlak, 2004). In fact, several studies have shown that a considerable fraction of the polar metabolites of E2 and EE2 can be cleaved in WWTPs, resulting in discharge of the initial compounds (Panter, Thompson, Beresford, \& Sumpter, 1999; Ternes et al., 1999; D’Ascenzo et al., 2003). On the other hand, Temes, Andersen, Gilberg, and Bonerz (2002) stressed that adsorption to sludge is important role in their removal from wastewaters. Consequently, the disposal of animal manure, wastewater, and sewage sludge to agricultural land can lead to the transfer of steroid hormones, including E2 and EE2, into soils, surface and ground waters (Stumpe \& Marschner, 2007). Another major source of steroid estrogens comes from the urban environment, mainly from human excretion, being released into WWT systems in either conjugated or unconjugated forms at micrograms per person and day levels (Johnson \& Sumpter, 2001; Johnson \& Williams, 2004).

Although the excreted estrogen conjugates are mostly considered to be biologically inactive, they may be converted back to their parent estrogens in the environment (Celiz et al., 2009). For instance, Ternes et al. (1999b) have already reported the deconjugation of $17 \beta$-estradiol-17 $\beta$-D-glucuronide and $17 \beta$-estradiol-3 $\beta$-D-glucuronide in activated sludge slurries, with increases in E1 and E2 concentrations. Glucuronide metabolite deconjugation in domestic wastewaters also occurs (D’Ascenzo et al., 2003). $\beta$-glucuronidase and arylsulfatase enzymes of $E$. coli (abundant in activated sludge) can deconjugate glucuronide and sulfate conjugates back to their active estrogen forms (Ternes et al., 1999; Matejicek, Houserova, \& Kuban, 2007).

Investigation of the effect of E2 in soils shows that its mineralization occurs co-metabolically and is limited by sorption, whereas testosterone seems to be utilized directly by soil microorganisms (Stumpe \& Marschner, 2007). Stumpe and Marschner (2007) found that E2 is more strongly sorbed into the soil matrix than testosterone. Regarding the biodegradation of E2 and EE2 in soils, it has been found that, despite their structural similarities, bacteria can cause E2 mineralization whereas EE2 seems to be mineralized by white-rot fungi (Stumpe \& Marschner, 2009).

Several environmental impacts could be related to exposure to E2 and EE2 affecting aquatic biota, soils, surface and ground waters (among 
others). Indeed, bodies of water with high estrogen levels, including downstream WWTPs effluents, may have a pronounced effect on aquatic species, leading to fish being feminized (McAvoy, 2008). Estrogens can deregulate and interfere with normal biological responses by mimicking natural hormones and disrupting signal pathways, like endocrine disrupters. Chronic exposure of fathead minnows (Pimephales promelas) to low E2 concentrations ( 5 to $6 \mathrm{ng} \mathrm{L}^{-1}$ ) feminize males through the production of vitellogenin (VTG) mRNA (evidenced by intersex changes in males), impact on gonadal development, and altered oogenesis in females (Kidd et al., 2007). EE2 also had the same effect (Bila \& Dezotti, 2007). Moreover, estrogens (including E2 and EE2) and their mimics can cause severe damage to fish populations, as shown by the rapid decrease fish stocks in contaminated lakes (Bila \& Dezotti, 2007; Kidd et al., 2007). Furthermore, fish reproductive rate can be reduced over 3 generations (Cripe et al., 2009), and Bila and Dezotti (2007) stated that E2 can affect egg production in turtles, as well as inducing blood VTG content.

Concerning the effect of the chronic exposure to contaminant estrogens in water and food products on humans, Swan, Liu, Overstreet, Brazil, and Skakkebaek (2007) found that hormones (used as growth promoters) were responsible for the reduction of the sperm count in the male offspring of women with a high red meat regime during gestation. Indeed, a number of studies have already shown that, over the past 60 years, the average sperm count in some countries has halved and the incidence of 33 malformations on the male reproductive system has doubled. Chronic exposure of adult males to estrogenic substances may result in breast growth and interference with the hypothalamus, pituitary and gonadal glandular systems, resulting in decreased libido, impotence, decreased androgen levels in the blood and decreased sperm count (Auger, Kunstmann, Czyglik, \& Jouannet, 1995; Waring \& Harris, 2005). Furthermore, contaminant estrogens, with relevance to EE2, are thought to induce some diseases, such as uterus, breast and prostate cancer, male fertility reduction, abnormal sexual development, abnormal thyroid glands, increased polycystic ovaries incidence, disturbances in ovarian functions, fertilization and pregnancy, endometriosis and neurobehavioral effects (Soto, Justicia, Wray, \& Sonnenschein, 1991; Adeel, Song, Wang, Francis, \& Yang, 2017; Verbinnen, Nunes, \& Vieira, 2010; Birnbaum \& Fenton, 2003; Coleman, Abdullah, Eggins, \& Palmer, 2005; Solomon \& Schettler, 2000; Gray, 1998; Daston et al., 1997). Finally, Sodré, Locatelli, Montagner, and Jardim (2007) emphasize that the embryonic stage is much more susceptible to estrogens compared to adults. Indeed, exposure at early stages of development can change developmental processes themselves, whereas at a more advanced stage they can solely interfere with reproduction or affect the offspring (Arcand-Hoy \& Benson, 1998). 


\section{Impact of PhACs in the microbial communities of WWT systems}

The main impacts of SMX, CBZ, E2, and EE2 in the microbial communities of biological WWT systems are discussed more fully in this section.

A few studies have already been conducted to understand the effect of SMX in microbial communities of WWTPs. Bacteria belonging to Betaproteobacteria and Gammaproteobacteria classes seemed to be the dominant species in WWT systems treating this compound (CydzikKwiatkowska \& Zielińska, 2016). Moreover, the disappearance of species belonging to the Sphingobacteria, Actinobacteria, Chloroflexi and Chlorobi classes suggests that these species are strongly affected by SMX in CAS systems (Collado et al., 2013). Similar results showed that bacteria belonging to Betaproteobacteria and Gammaproteobacteria were dominant in WWT systems with antibiotic removal using anoxic/oxic membrane biological reactor (A/O-MBR) processes. Indeed, monitoring Thiothrix spp. (Gammaproteobacteria) showed that the number of living cells increased due to its augmented antibiotic tolerance. However, in a different study (Novo, André, Viana, Nunes, \& Manaia, 2013), the SMX concentration and the abundance of antibiotic resistant cultivable bacteria in raw wastewaters from full-scale WWTPs were positively correlated with the abundance of Epsilonproteobacteria in treated wastewater and negatively correlated with Gammaproteobacteria, Betaproteobacteria and Firmicutes.Guo, Pang, Dou, and Yin (2017) found that SMX and chemical oxygen demand (COD) could change the structures of bacterial community within a sequencing batch reactor (SBR). However, Simpson's index of diversity and the Shannon-Weiner index values showed no significant change in bacterial diversity by these compounds. The sludge retention time (SRT) significantly influences the relative numbers of nitrifying bacteria (Xia et al. 2012). These results suggest that SMX may affect removal of nitrogenous compounds from biological systems, reducing the efficiency of ammonia nitrogen disposal (Guo et al., 2017). Other data help in elucidating the fact that denitrification processes are more vulnerable than nitrification and carbon oxidization processes under SMX stress. Indeed, the relative abundance of denitrifiers decreased by $86 \%$ at a SMX concentration of $2000 \mu \mathrm{g} \mathrm{L}^{-1}$ (Zhu et al., 2017).

Even though there is a significant lack of knowledge regarding the impact of anticonvulsants on microbial communities, according to Aubenneau, Tahar, Casellas, and Wisniewski (2010) some effects on both the respiratory activity of bacterial communities and on the bacterial agglomerate sizes could be related to $\mathrm{CBZ}$ exposure. And although no apparent inhibition occurs in the presence of $1 \mu \mathrm{g} \mathrm{L} \mathrm{L}^{-1}$ of CBZ, the oxygen uptake rate (OUR) increased under endogenous conditions. A possible explanation lies in an increase in the maintenance requirements as a result 
of CBZ-induced chemical stress. On the other hand, an OUR decrease was noted under exogenous conditions, which may be attributed to a change in the microbial community structure or the activity of individual species (Aubenneau et al., 2010). Cripe et al. (2009) found a negative effect of CBZ in the activity of the microbial communities of a MBR, leading to an initial OUR decrease, corresponding to the first CBZ dosing period. However, it was also noticed that from that moment onwards, the biomass behavior was quite similar with or without CBZ. Regarding the effect of CBZ in mixed microbial cultures (MMC) from full-scale WWTPs, growth inhibition was found relevant, being related to the CBZ concentration, especially under lower organic load conditions (Wang, Holzem, \& Gunsch, 2008). These results suggest that further studies should be encompass the ecological impacts of CBZ in WWTPs with different biological systems.

Due to the persistence of EE2 in the environment, it is necessary to carefully identify the microorganisms able to degrade this compound, including metabolic processes involved (Cajthaml, Křesinová, Svobodová, Sigler, \& Rezanka, 2009). Investigations are under way to better understand the effect of EE2 on activated sludge bacterial communities, and are showing that Firmicutes are negatively correlated with EE2 concentrations in a pilot scale reactor (Kruglova, Gonzalez-Martinez, Matilda Kråkström, Mikola, \& Vahala, 2017). Other studies, conducted to understand the effect on activated sludge microbial communities caused by EE2 assimilation under both aerobic and anaerobic conditions showed that microbial diversity decreased (Wang, Tam, \& Zhang, 2011). Furthermore, Proteobacteria were the predominant class (due to their EE2 biodegradation abilities), including Pseudomonas thermotolerans, Rhodanobacter lindaniclasticus, Azonexus caeni and Rhodanobacter sp. (Wang et al., 2011). As a result, EE2 biodegradation efficiencies were reported to be $\sim 80 \%$ under both aerobic and anaerobic conditions.

Regarding the biodegradation ability of E2 and its effects on the microbial communities in WWT systems, Pholcan, Baptista, Davenport, Sloan, and Curtis (2013) showed that decreasing microbial diversity was associated with a decline in E2 removal.

Given the lack of further significant published research on the impact of sulfonamides (and other antibiotics), anticonvulsants, and steroid estrogens in the microbial communities of WWT systems, and particularly of full-scale systems, additional studies are needed on these points of major interest.

\section{PhACs removal in biological WWT systems}

The increasing concern about the environmental and human health risks of PhACs led to the development of several removal technologies for these 
compounds, ranging from CAS, MBR and moving bed biofilm reactor (MBBR) systems to fungal and enzymatic treatments, among others (BadiaFabregat, Oller, \& Malato, 2017).

Among the most widely used, CAS and MBR systems have been 2 of the major options. In fact, MBR systems, which include biological degradation of organic matter coupled with membrane filtration, emerged during the last few years as a promising technology that surpass some of the limitations of the CAS treatment systems, such as limited SRT operational control and sludge settling (Radjenović et al., 2009). Taking this into consideration, the influence of operational and chemical parameters in CAS and MBR systems for PhACs removal will be addressed in the next section.

Knowledge of the PhACs key physicochemical properties seem to be relevant to the assessment of their removal efficiency in WWT systems (Stevens-Garmon, Drewes, Khan, McDonald, \& Dickenson, 2011; Hyland, Dickenson, Drewes, \& Higgins, 2012). Therefore, the most relevant physicochemical properties in this respect, including the water solubility and Log octanol-water coefficient (Log Kow) values for CBZ, SMX, E2 and EE2, are shown in the supplementary information (Tables 1-3). The Log Kow value has proved useful as a means of predicting biodegradation and sorption behavior (moderate sorption potential for organic compounds with Log Kow values between 2.5 and 4, and higher potential for values $>4$ ), for a number of different compounds (Martín, Camacho-Muñoz, Santos, Aparicio, \& Alonso, 2012; Rogers, 1996).

$\mathrm{PhACs}$ removal from wastewaters is receiving more attention over the last few years mainly due to their large environmental impact in surface waters, aquatic biota and soils, due to their inefficient removal by traditional biological WWT systems. Several technologies have been used to remove PhACs, including CAS, MBR and EMR systems, hybrid technologies (involving a number of different systems, such as biofilms and suspended biomass), and treatment with the Trametes versicolor fungi, among others. Taking this into consideration, the main biological WWT technologies used for sulfonamides, anticonvulsants and steroid estrogens removal, both in pilot-scale reactors and full-scale plants, will be described below.

\subsection{Full-scale WWTPs}

A significant number of studies have tried to determine the removal efficiencies of PhACs on full-scale WWTPs. A literature survey of the main works encompassing SMX, CBZ, E2 and EE2 removal efficiencies in fullscale WWTPs is presented in Table 3.

Elimination of SMX has been investigated in full-scale WWTP with different biological WWT systems by Göbel, Thomsen, McArdell, Joss, and 


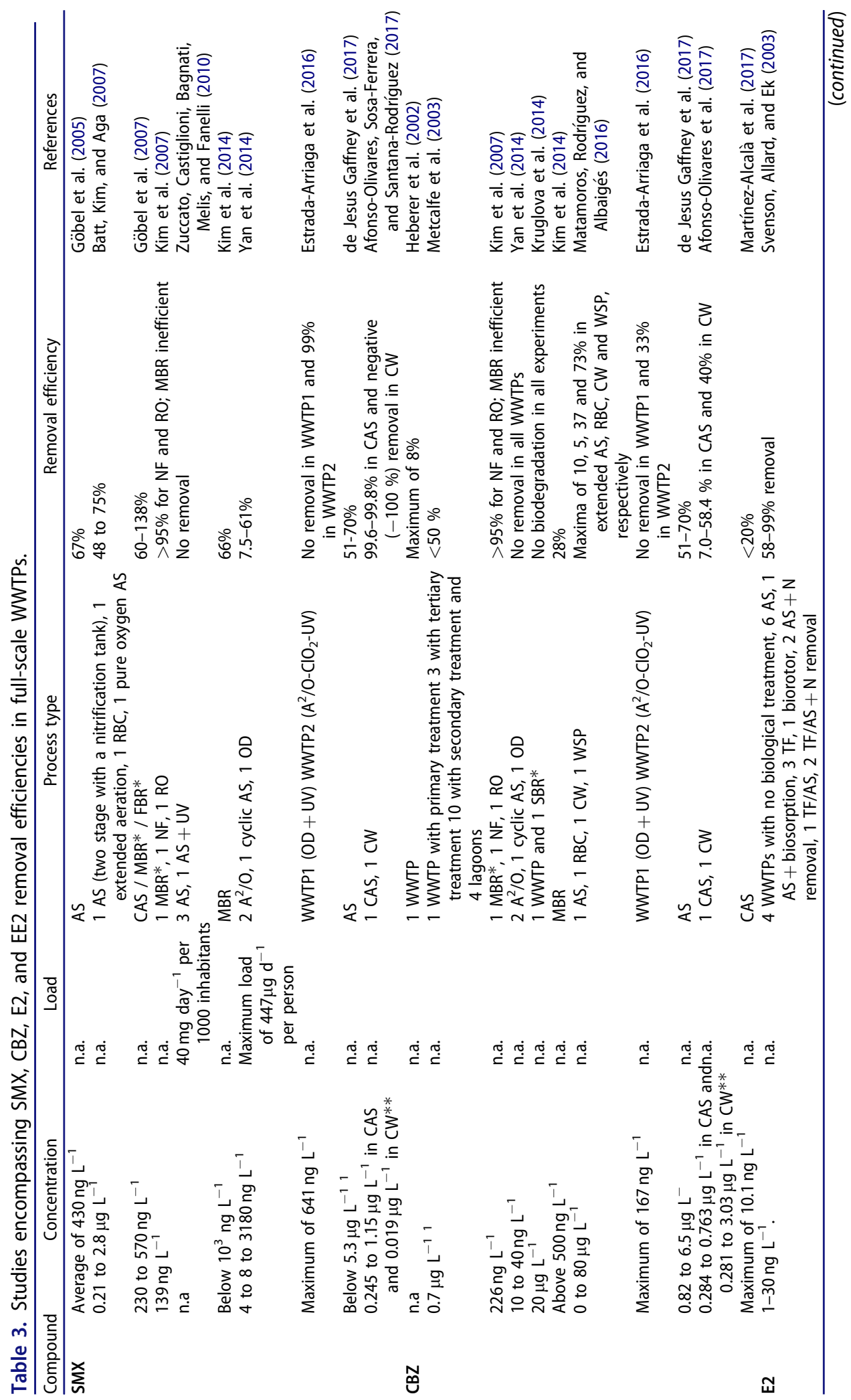




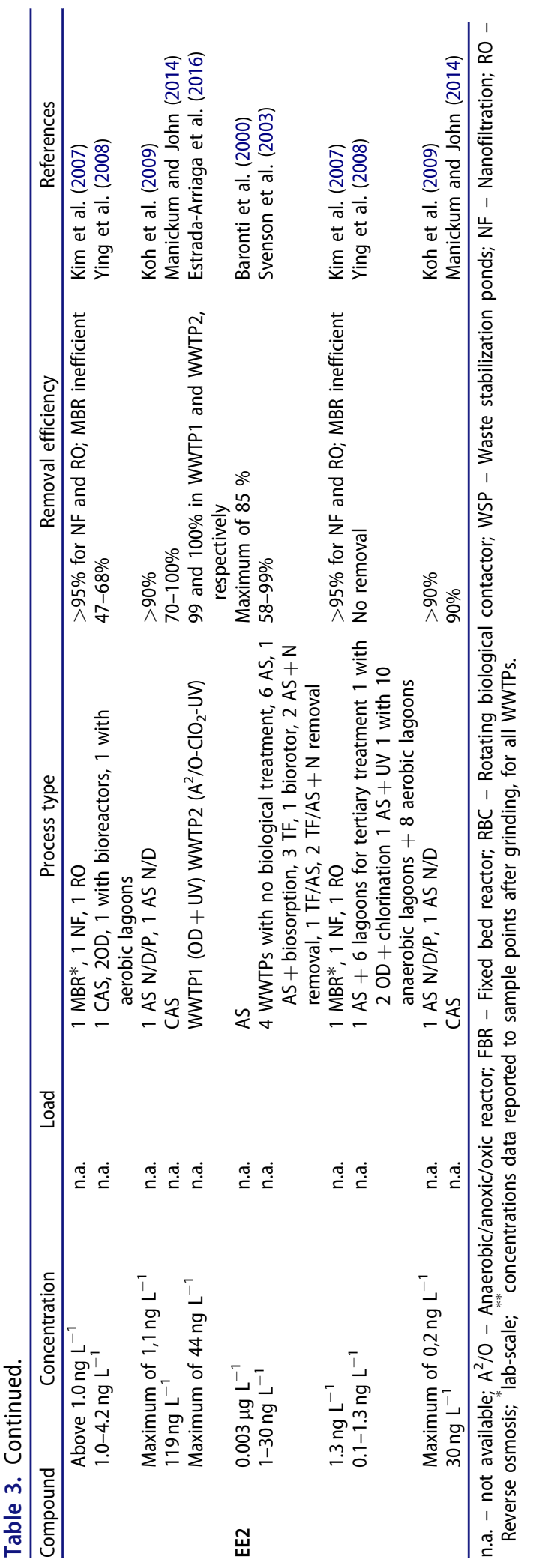


Giger (2005, Göbel, McArdell, Joss, Siegrist, \& Giger, 2007) and Polesel et al. (2016) among others. Removal of SMX in full-scale WWTPs occurs mainly by biotransformation, though deconjugation of metabolites back to the parent form can have a negative effect on the removal efficiency (Polesel et al., 2016). In this sense, the most commonly studied conjugated metabolite of SMX in full-scale WWTPs is N4-acetyl-SMX (Göbel et al., 2007), and the sorption of this metabolite can be considered negligible due to its chemical properties (Polesel et al., 2016).

CBZ remains recalcitrant in full-scale WWTPs due to its high solubility and low distribution coefficient between wastewater and sludge (Kruglova et al., 2014; Odize et al., 2017; Clara et al., 2005). Moreover, similar results showing slight or no removal were obtained for CBZ and 5 of its metabolites (10,11-dihydro-10,11-dihydroxy-CBZ, 10,11-dihydro-10-hydroxy-CBZ, 10,11-epoxy-10,11-dihydro-CBZ, 2-hydroxy-CBZ and 3-hydroxy-CBZ) in German and Portuguese full-scale WWTPs (Bahlmann et al., 2014). On the other hand, full-scale constructed wetlands (CW) were useful for CBZ and SMX removal purposes (Gross, Montgomery-Brown, Naumann, \& Reinhard, 2004; Matamoros, García, \& Bayona, 2008; Hijosa-Valsero, Matamoros, Martín-Villacorta, Bécares, \& Bayona, 2010; Anderson et al., 2013; Lee, Lee, Park, Kim, \& Cho, 2013). Nevertheless, conflicting results have been reported by these authors, ranging from no effective removal of both compounds in a study conducted in Canada (Anderson et al., 2013), from 15 to $37 \%$ CBZ removal efficiencies in full-scale and surface flow CW reported in Spain (Hijosa-Valsero et al., 2010).

With respect to estrogens, removal efficiencies of $>90 \%$ for E2 and EE2 in municipal WWTPs were obtained under both aerobic and anaerobic conditions (Joss, Andersen, Ternes, Richle, \& Siegrist, 2004). However, whereas E2 was oxidized and further eliminated by a CAS system in a WWTP in Germany, EE2 remained mainly persistent according to Ternes et al. (1999). In addition, investigations evaluating different full-scale WWTPs technologies were crucial for a deeper understanding of the removal process of estrogens. Braga et al. (2005) found that the removal efficiencies of estrogens were higher in WWTPs with microfiltration (MF), reverse osmosis (RO) and chlorination/dichlorination compared to the WWTP with $\mathrm{FeCl}_{3}$ addition. Taking into account the relatively low solids concentration in the enhanced primary treatment, the degree of estrogens partitioning in the organic fraction was thought to be responsible for the difference between the 2 plants. Miège et al., 2009 reported greater removal efficiencies for steroid estrogens in AS systems with nitrogen removal and membrane bioreactors. In addition, EE2 removal in fixed biomass reactors and waste stabilization ponds occurred predominantly in the liquid phase, under high solids retention time (SRT) conditions. Johnson et al. (2005) 
compared the concentration of steroid estrogens (E1, E2 and EE2) in treated effluents from different WWTPs presenting diverse WWT technologies, finding that the lowest estrogen removals occurred in the WWTP with solely a primary chemical treatment, whereas higher efficiencies were seen in WWTPs with AS and oxidation ditch (OD) systems.

With the purpose of understanding the behavior and the removal efficiencies of estrogens in a full-scale WWTP in Australia, Ying, Kookana, and Kumar (2008) showed that the removal rates of estrogens were consistent with the biochemical oxygen demand (BOD), mixed liquor suspended solids (MLSS) and ammonia removal efficiencies. Higher BOD, MLSS and ammonia values resulted in lower removal efficiencies of estrogens. Moreover, this study pointed out that the least efficient studied WWTP consisted of a series of anaerobic and aerobic lagoons whereas the most efficient was in CAS and OD systems.

\subsection{Influence of operational and chemical parameters in CAS and MBR systems}

As previously mentioned, the sustainable removal of PhACs from wastewaters is nowadays of major interest, and an increasing number of reports relating to the operational conditions and their removal efficiencies. To this effect, the main studies encompassing SMX, CBZ, E2 and EE2 removal efficiencies in $\mathrm{AS}$ and $\mathrm{MBR}$ systems under different operation conditions are presented in Table 4.

Keeping the above in mind, and with respect to sulfonamides, SMX is only partially removed in the primary treatment of WWTPs (Pérez, Eichhorn, \& Aga, 2005). On the other hand, Xia et al. (2012) showed that high SRT (>30 days) in the secondary treatment (using anoxic/aerobic membrane bioreactors - A/O-MBR) gave removal efficiencies $>80 \%$ for a number of antibiotics, including SMX. Nevertheless, comparable removal efficiency results have been obtained using an MBR operated with 15 to 30 days of SRT (Kimura, Hara, \& Watanabe, 2007; Tambosi et al., 2010), suggesting that the removal efficiency is not strictly related to this operational parameter. Given the dependency of SMX removal efficiencies under the SRT conditions, other reports were on the use of $2 \mathrm{MBR}$ systems at different SRT (15 and 30 days), with SMX removal efficiencies of, respectively, 55 and 64\% (Tambosi et al., 2010; Schröder et al., 2012). However, Suárez et al. (2010) showed that SMX degradation was independent of DO levels.

Regarding CAS systems, Yang et al. (2012) found that SMX was completely removed within $13 \mathrm{~h}$. However, comparing the SMX removal in CAS and MBR systems, others have shown diverse SMX removal efficiencies. Indeed, MBR 


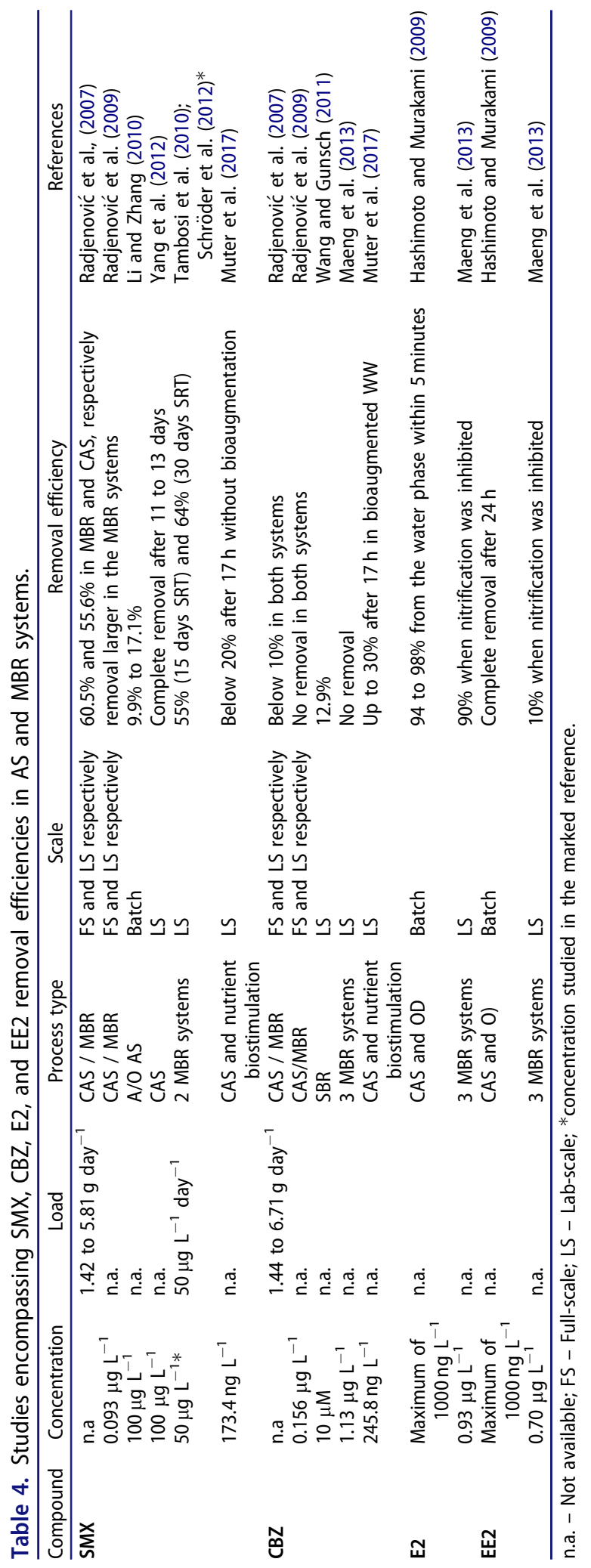


was for the most part more efficient for SMX removal than CAS systems (Radjenović, Petrovic, and Barceló, 2007; Radjenović et al., 2009).

A number of studies focusing on the use of CAS and MBR systems to remove CBZ have has given conflictive or even opposite results (Grandclément et al., 2017); these conflicting results are probably due to differences in the operating conditions of the CAS systems being compared, such as the SRT, hydraulic retention time (HRT) or MLSS, but also to the sludge and the wastewaters chemical composition (Grandclément et al., 2017). A number of other investigations have shown that CAS systems are largely inefficient for the removal of $\mathrm{CBZ}$ due to the deconjugation (during the WWT) of conjugates by hydrolysis, which could lead to an increase of the contaminant load. Indeed, the CBZ removal inefficiency is well known to be related to its chemical properties (Mohapatra et al., 2014).

Contrary to SMX, studies on the relationship between the operational conditions in a MBR reactor and CBZ removal efficiencies showed that this compound remains recalcitrant regardless of the SRT values (Bernhard, Müller, \& Knepper, 2006; Maeng, Choi, Lee, \& Song, 2013). Furthermore, and regarding the influence of the HRT (Gros, Petrović, Ginebreda, \& Barceló, 2010) and pH (Tadkaew, Sivakumar, Khan, McDonald, \& Nghiem, 2010), the CBZ removal efficiency also did not show any clear relationship between these parameters. Several other studies have compared removal efficiencies of several PhACs by CAS and MBR systems, including CBZ. According to Bernhard et al., (2006), MBR had higher removal efficiencies than CAS regarding a number of polar contaminants, whereas recalcitrant compounds, e.g. CBZ, were not eliminated.

Regarding the removal and biodegradation efficiencies of estrogens, reports include both pilot-scale reactors and full-scale plants; as a result, crucial knowledge about these compounds structures, their transformation pathways, and the relation between removal efficiencies and operational conditions has emerged (Cajthaml et al., 2009; Liu et al., 2015; Ting \& Praveena, 2017). Regarding the temperature effect on the removal efficiencies of estrogens, a higher efficiency is found in summer (average $26.4{ }^{\circ} \mathrm{C}$ ) than in winter (average $16.4^{\circ} \mathrm{C}$ ) (Nakada et al., 2006). However, Suárez et al. (2012) found higher removal efficiencies of EE2 in CAS systems in the temperature at $10-35^{\circ} \mathrm{C}$ than above $45^{\circ} \mathrm{C}$.

Iit is well known that estrogens (e.g. E2 and EE2) removal can also be affected by other conditions, including SRT and HRT values and MLSS contents. Indeed, high SRT (especially from 20 to 24 days) leads to higher efficiencies of the removal on estrogens (Clara, Kreuzinger, Strenn, Gans, \& Kroiss, 2005; Carballa, Omil, Ternes, \& Lema, 2007; McAdam et al., 2010; Petrie, McAdam, Hassard, Stephenson, Lester, \& Cartmell, 2014). With respect to the MLSS influence, there have been contradictory results; while Suzuki and 
Maruyama, (2006) reported no differences in removal efficiencies in CAS systems, varying the MLSS from $1619 \mathrm{mg} \mathrm{L}^{-1}$ to $1921 \mathrm{mg} \mathrm{L}^{-1}$, Chen and $\mathrm{Hu}$ (2009) and Li, Yuasa, Obara, and Mathews, (2005) showed increased efficiency in batch tests by varying the MLSS from $4 \mathrm{~g} \mathrm{~L}^{-1}$ to $12.5 \mathrm{~g} \mathrm{~L}^{-1}$, and from $435 \mathrm{mg} \mathrm{L}^{-1}$ to $1750 \mathrm{mg} \mathrm{L}^{-1}$, respectively. Suárez et al. (2010) showed that removal efficiencies of $99 \%$ for E2and $87 \%$ for EE2 with regard to the influence of HRT could be obtained with a $24 \mathrm{~h}$ HRT (for a MLVSS of $1.6 \mathrm{~g} \mathrm{~L}^{-1}$ and a temperature range from 16 to $20^{\circ} \mathrm{C}$ ) in CAS systems. These results suggest that other factors besides temperature, HRT, SRT and MLSS, e.g. the initial estrogens concentration, could play a major role in their removal processes. In fact, other operational conditions were found relevant in improving the biodegradation kinetics of EE2 in CAS processes, including the food to microorganism ratio (F/M). Ziels, Lust, Gough, Strand, and Stensel (2014) indicated that population selection, in low organic substrate concentrations, can improve EE2 biodegradation kinetics. Maeng et al. (2013) obtained better removal efficiencies for E2 than EE2 in MBR systems when nitrification was inhibited. In this sense, more work is needed to clarify the influence of the above parameters in E2 and EE2 removal efficiencies in WWTPs.

Although Hashimoto and Murakami (2009) showed that estrogens can be completely removed after $24 \mathrm{~h}$ in batch experiments using samples from CAS and OD full-scale WWTPs, Kim, Cho, Kim, Vanderford, and Snyder (2007) results suggest that MBR could be more efficient in hormones (estriol, testosterone, androstenedione) removal from wastewaters than CAS systems.

In comparing PhACs removal efficiencies between the CAS and MBR systems favoring the latter, it should be emphasized that these results could be partially explained by the differences in the operational conditions (e.g. SRT). Nonetheless, it is also known that the floc surface, per reactor volume, is 10 times higher in MBR than in CAS, suggesting that the contact between microorganisms and pollutants could be favored in MBR, thus stimulating enzymatic activity (Cirja, Ivashechkin, Schäffer, \& Corvini, 2008). However, it should be noted that natural and human originated metabolites and PhACs by-products can be even more toxic than the parent compounds, such as chlorine by-products in disinfection (Buttiglieri \& Knepper, 2008).

\subsection{Fungi treatments, EMR and HS}

In the last few years, a number of different WWT methodologies, e.g. fungi treatments, EMR and HS, have been examined regarding the removal of PhACs from wastewaters. To this effect, the major reports encompassing SMX, CBZ, E2 and EE2 removal efficiencies using these systems are presented in Table 5. Rodarte-Morales, Feijoo, Moreira, and Lema (2011) 


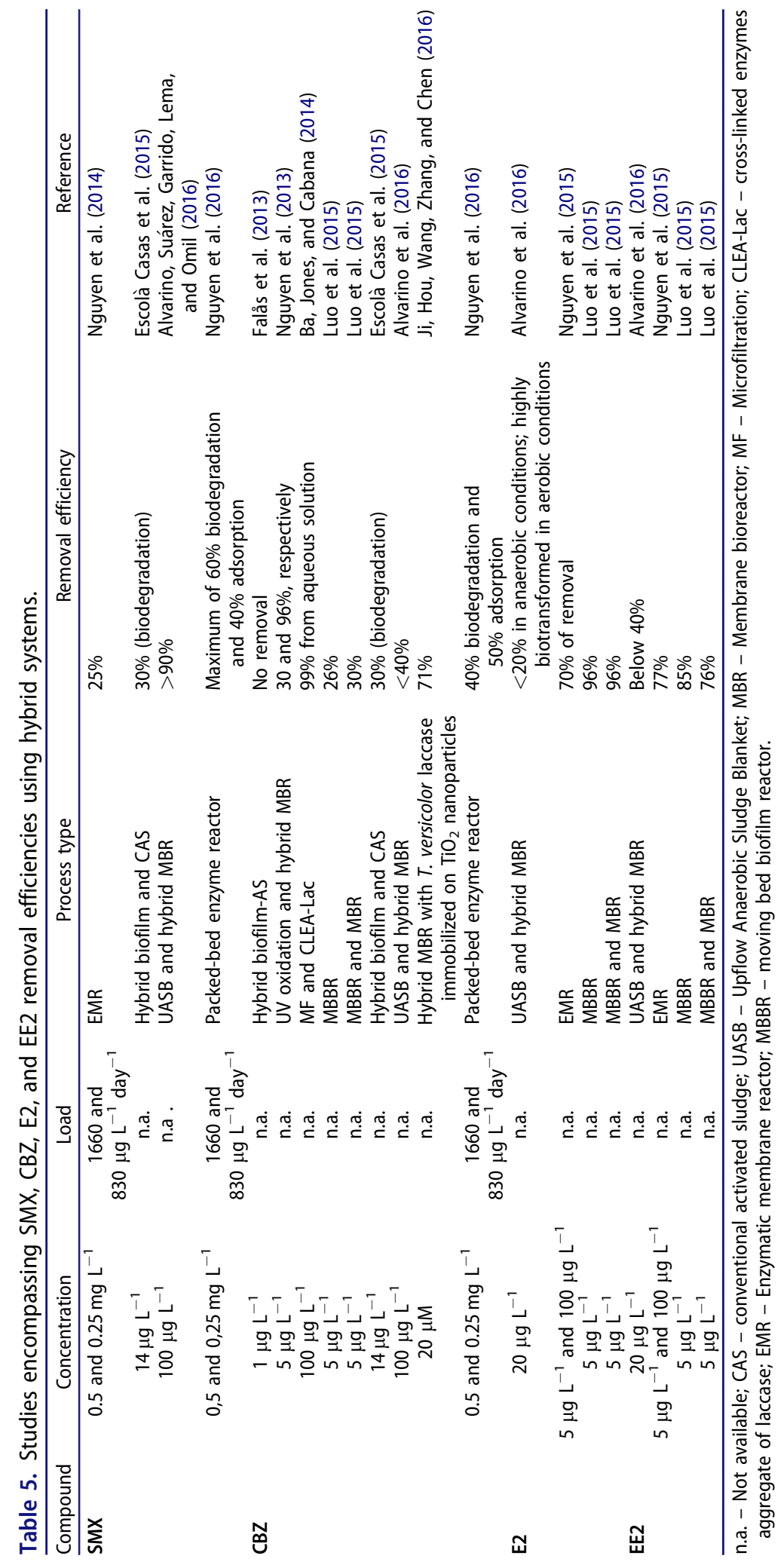


focusing on the removal of SMX using white rot fungi, found complete degradation after 14 days of incubation with the 3 fungal strains (an anamorph species of Bjerkandera sp. R1, Bjerkandera adusta and Phanerochaete chrysosporium). Fungi were also of interest in the degradation of estrogens (E2 and EE2), including the use of laccase from T. versicolor (Auriol, Filali-Meknassi, Tyagi, \& Adams, 2007) and other enzymatic solutions. In fact, $M n P$ solutions produced by $P$. ostreatus gave an $80 \%$ EE2 removal efficiency (Cajthaml et al., 2009; Suzuki, Hirai, Murata, \& Nishida, 2003). Others showed that enzymatic reactions mediated by vanillin, p-coumaric acid or ferulic acid achieved EE2 removal percentages ranging from 80 to $100 \%$ after $24 \mathrm{~h}$ (Nguyen, Hai, Kang, Price, \& Nghiem, 2013).

Significant research has also been developed to achieve CBZ removal using fungi treatments. One of the most employed organisms in CBZ removal from aqueous media is T. versicolor; Jelic et al. (2012) reported a high removal efficiency (96\%) using an air-pulsed fluidized bed bioreactor operated under batch conditions. On the contrary, Cruz-Morató et al. (2013) found that the deconjugation of CBZ intermediates led to increased CBZ in a fluidized bed bioreactor treating real wastewater with T. versicolor. Others have also exploited the potential of commercial fungi (e.g. T. versicolor) based enzymes; Tran, Urase, and Kusakabe (2010) reported CBZ removal efficiencies just under $40 \%$ with commercial laccase. Phanerochaete chrysosporium fungi has also been used to evaluate in vitro degradation of CBZ. Zhang and Geissen (2010) batch experiments yielded poor (mostly $<10 \%$ ) to no CBZ removal abilities using $P$. chrysosporium lignin peroxidase $(L i P)$. On the contrary, the use of manganese peroxidase $(M n P)$ solutions produced by Pleurotus ostreatus degraded 98\% of CBZ (Zhang \& Geissen, 2010; Golan-Rozen, Chefetz, Ben-Ari, Geva, \& Hadar, 2011).

However, there have been conflicting results regarding a wider range of PhACs removal strategies. Thus, the interest in studying HS by combining one or more treatment processes for this purpose has been increasing. Tang et al. (2017) found poor removal SMX efficiencies $(\sim 10 \%)$ and CBZ recalcitrance in a polishing $\mathrm{MBBR}$. In fact, poor removal $\mathrm{CBZ}$ efficiencies had been reported beforehand in a hybrid biofilm-activated sludge process and in a MBBR (Falås et al., 2013; Luo et al., 2014). On the contrary, 80\% of $\mathrm{CBZ}$ removal was obtained in an integrated fixed-film activated sludge membrane bioreactor (IFAS-MBR) (De La Torre et al., 2015). In another study, a hybrid biofilm and activated sludge system (Hybas ${ }^{\mathrm{TM}}$ ) has been used for hospital wastewater (containing SMX and CBZ) treatment, obtaining $\sim 30 \%$ in removal efficiency for both compounds (Escolà Casas et al. 2015). Regarding steroid estrogens removal in hybrid systems, De la Torre et al. (2015) achieved complete (100\%) E2 and EE2 removal in an IFAS- 
MBR, whereas removal efficiencies $>80 \%$ were obtained by Luo et al. (2014) using a sponge-based MBBR.

\section{Concluding remarks and future perspectives}

PhACs, including sulfonamides, anticonvulsants and estrogens, are widely present in municipal sewage, largely due to human excretion, causing serious environmental damage. Although a number of different biological WWT systems can be found in WWTPs, AS and MBR systems remain the most widely operated. However, these systems have shown - for the most part - inefficiency in the removal of these compounds, with serious consequences to aquatic life and human health. With this in mind, concern over the development of new sustainable removal technologies is increasing, including EMR, fungi treatments and HS. Therefore, the main commonly employed biological WWT systems for PhACs removal, particularly sulfonamides (SMX), anticonvulsionants (CBZ) and steroid estrogens (E2 and EE2) are being addressed, as well as their main environmental impacts, mainly in terms of aquatic biota, soil and human health.

Although AS systems (including CAS, SBR, OD and other configurations) are frequently inefficient in the removal of PhACs (including CBZ, SMX, E2, and EE2), a number of different investigations focusing on the removal efficiencies of these systems have been published. In fact, several factors have been thoroughly studied, including different PhAC concentrations, system configurations, and diverse chemical and operational conditions. Furthermore, it has also been found that MBR systems are more suitable and efficient than CAS systems. That being the case, more research is required to enlighten and corroborate these previous findings.

Despite the undertaken efforts regarding CAS and MBR systems, it should be pointed out that some PhACs, e.g. CBZ, remain recalcitrant in these systems; thus, the development of EMR, fungi treatments and HS removal methodologies is a major focus of interest. Again, a number of different strategies for the removal of SMX, CBZ, E2 and EE2 for such technologies have been published, although with varying removal efficiencies being reported.

The evaluation of the above technologies in terms of cost-benefit should also be exploited to achieve sustainable implementation in full-scale WWTPs. In this sense, future studies encompassing the use of alternative technologies (e.g. aerobic granular sludge) for PhACs removal are needed. Further investigation should also address the problem of improving the ability of these technologies to achieve sustainable removal of PhACs, and to understand the relationships between the operational parameters and correspondent removal efficiencies. Moreover, long-term exposure 
(chronic) effects of products resulting from PhACs degradation should be also investigated in future studies.

\section{Acknowledgments}

The final presentation of this manuscript was carried out by BioMedES UK. (www.biomedes.biz).

\section{Funding}

Cristiano Leal is recipient of a fellowship supported by a doctoral advanced training (call NORTE-69-2015-15) funded by the European Social Fund under the scope of Norte2020 Programa Operacional Regional do Norte. The authors thank the Portuguese Foundation for Science and Technology (FCT) under the scope of the strategic funding of UID/BIO/ 04469 unit, COMPETE 2020 (POCI-01-0145-FEDER-006684) and BioTecNorte operation (NORTE-01-0145-FEDER-000004) funded by the European Regional Development Fund under the scope of Norte2020 - Programa Operacional Regional do Norte.

\section{ORCID}

Cristiano S. Leal (D) http://orcid.org/0000-0002-0383-4727

Daniela P. Mesquita (D) http://orcid.org/0000-0002-0421-6736

António Luís Amaral (D) http://orcid.org/0000-0002-2927-6129

Eugénio C. Ferreira (D) http://orcid.org/0000-0002-5400-3333

\section{References}

Adeel, M., Song, X., Wang, Y., Francis, D., \& Yang, Y. (2017). Environmental impact of estrogens on human, animal and plant life: A critical review. Environment International, 99, 107. doi:10.1016/j.envint.2016.12.010

Afonso-Olivares, C., Sosa-Ferrera, Z., \& Santana-Rodríguez, J. J. (2017). Occurrence and environmental impact of pharmaceutical residues from conventional and natural wastewater treatment plants in Gran Canaria (Spain). Science of the Total Environment, 599-600, 934-943. doi:10.1016/j.scitotenv.2017.05.058

Ahmed, M. B., Zhou, J. L., Ngo, H. H., Guo, W., Thomaidis, N. S., \& Xu, J. (2017). Progress in the biological and chemical treatment technologies for emerging contaminant removal from wastewater: A critical review. Journal of Hazardous Materials, 23, 274-298. doi:10.1016/j.jhazmat.2016.04.045

Ali, S. M. H. (2014). Degradation and biological assessment of aqueous micropollutant mixtures. MSc Thesis. University of Western Ontario, London, Canada.

Alvarino, T., Suárez, S., Garrido, M., Lema, J. M., \& Omil, F. (2016). A UASB reactor coupled to a hybrid aerobic MBR as innovative plant configuration to enhance the removal of organic micropollutants. Chemosphere, 144, 452-458. doi:10.1016/j.chemosphere.2015.09.016

Anderson, J. C., Carlson, J. C., Low, J. E., Challis, J. K., Wong, C. S., Knapp, C. W., \& Hanson, M. L. (2013). Performance of a constructed wetland in Grand Marais, Manitoba, Canada: Removal of nutrients, pharmaceuticals, and antibiotic resistance genes 
from municipal wastewater. Chemistry Central Journal, 7(1), 54-69. doi:10.1186/1752153X-7-54

Anderson, P. D., Johnson, A. C., Pfeiffer, D., Caldwell, D. J., Hannah, R., Mastrocco, F., ... Williams, R. J. (2012). Endocrine disruption due to estrogens derived from humans predicted to be low in the majority of U.S. surface waters. Environmental Toxicology and Chemistry, 31(6), 1407-1415. doi:10.1002/etc.1824

Andreozzi, R., Raffaele, M., \& Nicklas, P. (2003). Pharmaceuticals in STP effluents and their solar photodegradation in aquatic environment. Chemosphere, 50(10), 1319-1330. doi:10. 1016/S0045-6535(02)00769-5

Arcand-Hoy, L. D., \& Benson, W. H. (1998). Fish reproduction: An ecologically relevant indicator of endocrine disruption. Environmental Toxicology and Chemistry, 17(1), 49-57. doi:10.1897/1551-5028(1998)017<0049:FRAERI > 2.3.CO;2

Ashton, D., Hilton, M., \& Thomas, K. V. (2004). Investigating the environmental transport of human pharmaceuticals to streams in the United Kingdom. Science of the Total Environment, 333(1-3), 167-184. doi:10.1016/j.scitotenv.2004.04.062

Aubenneau, M., Tahar, A., Casellas, C., \& Wisniewski, C. (2010). Membrane bioreactor for pharmaceutically active compounds removal: Effects of carbamazepine on mixed microbial communities implied in the treatment. Process Biochemistry, 45(11), 1826-1831. doi: 10.1016/j.procbio.2010.04.011

Aubertheau, E., Stalder, T., Mondamert, L., Ploy, M. C., Dagot, C., \& Labanowski, J. (2017). Impact of wastewater treatment plant discharge on the contamination of river biofilms by pharmaceuticals and antibiotic resistance. Process Biochem, 579, 1387-1398. doi:10.1016/j.scitotenv.2016.11.136

Auger, J., Kunstmann, J. M., Czyglik, F., \& Jouannet, P. (1995). Decline in semen quality among fertile men in Paris during the past 20 years. New England Journal of Medicine, 332(5), 281-285.

Auriol, M., Filali-Meknassi, Y., Tyagi, R. D., \& Adams, C. D. (2007). Laccase-catalyzed conversion of natural and synthetic hormones from a municipal wastewater. Water Research, 41(15), 3281-3288. doi:10.1016/j.watres.2007.05.008

Avberšek, M., Šömen, J., \& Heath, E. (2011). Dynamics of steroid estrogen daily concentrations in hospital effluent and connected waste water treatment plant. Journal of Environmental Monitoring, 13(8), 2221-2226. doi:10.1039/c1em10147a

Ba, S., Jones, J. P., \& Cabana, H. (2014). Hybrid bioreactor (HBR) of hollow fiber microfilter membrane and cross-linked laccase aggregates eliminate aromatic pharmaceuticals in wastewaters. Journal of Hazardous Materials, 280, 662-670. doi:10.1016/j.jhazmat.2014. 08.062

Badia-Fabregat, M., Oller, I., \& Malato, S. (2017). Overview on pilot-scale treatments and new and innovative technologies for hospital effluent. In P. Verlicchi (Eds.), The handbook of environmental chemistry (pp. 1-22). Cham: Springer-Verlag.

Bahlmann, A., Brack, W., Schneider, R. J., \& Krauss, M. (2014). Carbamazepine and its metabolites in wastewater: Analytical pitfalls and occurrence in Germany and Portugal. Water Research, 57, 104-114. doi:10.1016/j.watres.2014.03.022

Bahlmann, A., Weller, M. G., Panne, U., \& Schneider, R. J. (2009). Monitoring carbamazepine in surface and wastewaters by an immunoassay based on a monoclonal antibody. Analytical and Bioanalytical Chemistry, 395(6), 1809-1820. doi:10.1007/s00216-009-2958-7

Baronti, C., Curini, R., D’Ascenzo, G., Di Corcia, A., Gentili, A., \& Samperi, R. (2000) Monitoring natural and synthetic estrogens at activated sludge sewage treatment plants and in a receiving river water. Environmental Science \& Technology, 34, 5059-5066. 
Batt, A. L., Kim, S., \& Aga, D. S. (2007). Comparison of the occurrence of antibiotics in four full-scale wastewater treatment plants with varying designs and operations. Chemosphere, 68(3), 428-435. doi:10.1016/j.chemosphere.2007.01.008

Bennett, G. D., Amore, B. M., Finnell, R. H., Wlodarczyk, B., Kalhorn, T. F., Skiles, G. L., ... Slattery, J. T. (1996). Teratogenicity of carbamazepine-10,11-epoxide and oxcarbazepine in the SWV mouse. Journal of Pharmacology and Experimental Therapeutics, 279(3), 1237-1242.

Bernhard, M., Müller, J., \& Knepper, T. P. (2006). Biodegradation of persistent polar pollutants in wastewater: Comparison of an optimised lab-scale membrane bioreactor and activated sludge treatment. Water Research, 40(18), 3419-3428. doi:10.1016/j.watres.2006. 07.011

Besha, A. T., Gebreyohannes, A. Y., Tufa, R. A., Bekele, D. N., Curcio, E., \& Giorno, L. (2017). Removal of emerging micropollutants by activated sludge process and membrane bioreactors and the effects of micropollutants on membrane fouling: A review. Journal of Environmental Chemical Engineering, 5(3), 2395-2414. doi:10.1016/j.jece.2017.04.027

Bila, D. M., \& Dezotti, M. (2007). Desreguladores endócrinos no meio ambiente: Efeitos e consequências. Química Nova, 30(3), 651-666. doi:10.1590/S0100-40422007000300027

Birnbaum, L. S., \& Fenton, S. E. (2003). Cancer and developmental exposure to endocrine disruptors. Environmental Health Perspectives, 111(4), 389-394. doi:10.1289/ehp.5686

Bonvin, F., Chevre, N., Rutler, R., \& Kohn, T. (2012). Pharmaceuticals and their human metabolites in Lake Geneva: Occurrence, fate and ecotoxicological relevance. Archives of Science, 65, 143-156.

Braga, O., Smythe, G. A., Schäfer, A. I., \& Feitz, A. J. (2005). Fate of steroid estrogens in Australian inland and coastal wastewater treatment plants. Environmental Science \& Technology, 39(9), 3351-3358. doi:10.1021/es0501767

Brain, R. A., Ramirez, A. J., Fulton, B. A., Chambliss, C. K., \& Brooks, B. W. (2008) Herbicidal effects of sulfamethoxazole in Lemna gibba: Using p-aminobenzoic acid as a biomarker of effect. Environmental Science \& Technology, 42, 8965-8970.

van den Brandhof, E. J., \& Montforts, M. (2010). Fish embryo toxicity of carbamazepine, diclofenac and metoprolol. Ecotoxicology and Environmental Safety, 73(8), 1862-1866. doi:10.1016/j.ecoenv.2010.08.031

Buttiglieri, G., \& Knepper, T. P. (2008). Removal of emerging contaminants in wastewater treatment: Conventional activated sludge treatment. In Emerging contaminants from industrial and municipal waste. S2, No. November 2008, 5 (pp. 1-35).

Cajthaml, T., Křesinová, Z., Svobodová, K., Sigler, K., \& Řezanka, T. (2009). Microbial transformation of synthetic estrogen 17 $\alpha$-ethinylestradiol. Environmental Pollution, 157(12), 3325-3335. doi:10.1016/j.envpol.2009.06.027

Calamari, D., Zuccato, E., Castiglioni, S., Bagnati, R., \& Fanelli, R. (2003). Strategic survey of therapeutic drugs in the rivers Po and lambro in Northern Italy. Environmental Science \& Technology, 37(7), 1241-1248. doi:10.1021/es020158e

Carabin, A., Drogui, P., \& Robert, D. (2015). Photo-degradation of carbamazepine using $\mathrm{TiO} 2$ suspended photocatalysts. Journal of the Taiwan Institute of Chemical Engineers, 54, 109-117. doi:10.1016/j.jtice.2015.03.006

Carballa, M., Omil, F., Ternes, T., \& Lema, J. M. (2007). Fate of pharmaceutical and personal care products (PPCPs) during anaerobic digestion of sewage sludge. Water Research, 41(10), 2139-2150. doi:10.1016/j.watres.2007.02.012

Caldwell, D. J., Mastrocco, F., Anderson, P. D., Lange, R., \& Sumpter, J. P. (2012). Predicted-no-effect concentrations for the steroid estrogens estrone $17 \beta$-estradiol, estriol 
and 17a-ethinylestradiol. Environmental Toxicology and Chemistry, 31(6), 1396-1406. doi:10.1002/etc. 1825

Cavallucci, S. (2007). What's topping the charts in prescription drugs this year? Pharmacy Practice, 23, 25-32.

Celiz, M. D., Tso, J., \& Aga, D. S. (2009). Pharmaceutical metabolites in the environment: Analytical challenges and ecological risks. Environmental Toxicology and Chemistry, 28(12), 2473-2484. doi:10.1897/09-173.1

Chen, X., \& Hu, J. (2009). Degradation of $17 \beta$-estradiol and its conjugates: Effects of initial concentration and MLSS concentration. Process Biochemistry, 44(12), 1330-1334. doi:10. 1016/j.procbio.2009.07.007

Choquet-Kastylevsky, G., Vial, T., \& Descotes, J. (2002). Allergic adverse reactions to sulfonamides. Current Allergy and Asthma Reports, 2, (1), 16-25.

Christou, A., Kyriacou, M. C., Georgiadou, E. C., Papamarkou, R., Hapeshi, E., Karaolia, P., ... Fatta-Kassinos, D. (2019). Uptake and bioaccumulation of three widely prescribed pharmaceutically active compounds in tomato fruits and mediated effects on fruit quality attributes. Science of the Total Environment, 647, 1169-1178. doi:10.1016/j.scitotenv.2018. 08.053

Cirja, M., Ivashechkin, P., Schäffer, A., \& Corvini, P. F. X. (2008). Factors affecting the removal of organic micropollutants from wastewater in conventional treatment plants (CTP) and membrane bioreactors (MBR). Reviews in Environmental Science and Bio/ Technology, 7(1), 61-78. doi:10.1007/s11157-007-9121-8

Clara, M., Strenn, B., Gans, O., Martinez, E., Kreuzinger, N., \& Kroiss, H. (2005). Removal of selected pharmaceuticals, fragrances and endocrine disrupting compounds in a membrane bioreactor and conventional wastewater treatment plants. Water Research, 39(19), 4797-4807. doi:10.1016/j.watres.2005.09.015

Clara, M., Kreuzinger, N., Strenn, B., Gans, O., \& Kroiss, H. (2005). The solids retention time - A suitable design parameter to evaluate the capacity of wastewater treatment plants to remove micropollutants. Water Research, 39(1), 97-106. doi:10.1016/j.watres. 2004.08.036

Clara, M., Strenn, B., \& Kreuzinger, N. (2004). Carbamazepine as a possible anthropogenic marker in the aquatic environment: Investigations on the behaviour of Carbamazepine in wastewater treatment and during groundwater infiltration. Water Research, 38(4), 947-954. doi:10.1016/j.watres.2003.10.058

Coleman, H. M., Abdullah, M. I., Eggins, B. R., \& Palmer, F. L. (2005). Photocatalytic degradation of $17 \beta$-oestradiol, oestriol and $17 \alpha$-ethynyloestradiol in water monitored using fluorescence spectroscopy. Applied Catalysis B, Environmental, 55(1), 23-30. doi:10.1016/ j.apcatb.2004.07.004

Collado, N., Buttiglieri, G., Marti, E., Ferrando-Climent, L., Rodriguez-Mozaz, S., Barceló, D., ... Rodriguez-Roda, I. (2013). Effects on activated sludge bacterial community exposed to sulfamethoxazole. Chemosphere, 93(1), 99-106. doi:10.1016/j.chemosphere. 2013.04.094

Combalbert, S., \& Hernandez-Raquet, G. (2010). Occurrence, fate, and biodegradation of estrogens in sewage and manure. Applied Microbiology and Biotechnology, 86(6), 1671-1692. doi:10.1007/s00253-010-2547-x

Cripe, G. M., Hemmer, B. L., Goodman, L. R., Fournie, J. W., Raimondo, S., Vennari, J. C., ... Hemmer, M. J. (2009). Multigenerational Exposure of the Estuarine Sheepshead Minnow (_Cyprinodon variegatus_) to $17 \beta$-Estradiol. I. organism-level effects over three generations. Environmental Toxicology and Chemistry, 28(11), 2397-2408. doi:10.1897/ 08-542.1 
Cruz-Morató, C., Ferrando-Climent, L., Rodriguez-Mozaz, S., Barceló, D., Marco-Urrea, E., Vicent, T., \& Sarrà, M. (2013). Degradation of pharmaceuticals in non-sterile urban wastewater by Trametes versicolor in a fluidized bed bioreactor. Water Research, 47(14), 5200-5210. doi:10.1016/j.watres.2013.06.007

Cui, C. W., Ji, S. L., \& Ren, H. Y. (2006). Determination of steroid estrogens in wastewater treatment plant of a controceptives producing factory. Environmental Monitoring and Assessment, 121, 407-417.

Cydzik-Kwiatkowska, A., \& Zielińska, M. (2016). Bacterial communities in full-scale wastewater treatment systems. World Journal of Microbiology and Biotechnology, 32, 1-8.

Danner, M.-C., Robertson, A., Behrends, V., \& Reiss, J. (2019). Antibiotic pollution in surface fresh waters: Occurrence and effects. Science of the Total Environment, 664, 793-804. doi:10.1016/j.scitotenv.2019.01.406

Daston, G. P., Gooch, J. W., Breslin, W. J., Shuey, D. L., Nikiforov, A. I., Fico T. A., \& Gorsuch, J. W. (1997) Environmental estrogens and reproductive health: a discussion of the human, environmental data. Reproductive Toxicology, 11(4), 465-481.

D’Ascenzo, G., Di Corcia, A., Gentili, A., Mancini, R., Mastropasqua, R., Nazzari, M., \& Samperi, R. (2003). Fate of natural estrogen conjugates in municipal sewage transport and treatment facilities. Science of the Total Environment, 302(1-3), 199-209. doi:10. 1016/S0048-9697(02)00342-X

Demoling, L. A., Bååth, E., Greve, G., Wouterse, M., \& Schmitt, H. (2009). Effects of sulfamethoxazole on soil microbial communities after adding substrate. Soil Biology and Biochemistry, 41(4), 840-848. doi:10.1016/j.soilbio.2009.02.001

Desbrow, C., Routledge, E. J., Brighty, G. C., Sumpter, J. P., \& Waldock, M. (1998). Identification of estrogenic chemicals in STW effluent. 1. Chemical fractionation and in vitro biological screening. Environmental Science \& Technology, 32(11), 1549-1558. doi: 10.1021/es9707973

Donner, E., Kosjek, T., Qualmann, S., Kusk, K. O., Heath, E., Revitt, D. M., ... Andersen, H. R. (2013). Ecotoxicity of carbamazepine and its UV photolysis transformation products. Science of the Total Environment, 443, 870-876. doi:10.1016/j.scitotenv.2012.11.059

Dray, J., Dray, T. F., \& Ullmann, A. (1972). Hydrolysis of Urinary Metabolites of Different Steroid Hormones by -Glucuronidase From Escherichia Coli. Annales de l'Institut Pasteur (Paris), 123(6), 853-857.

Drugbank. (2016a). The drugbank database. Carbamazepine. Available: https://www.drugbank.ca/drugs/DB00564 [visited at 12/02/2016]

Drugbank. (2016b). The drugbank database. Sulfamethoxazole. Available: https://www.drugbank.ca/drugs/DB01015 [visited at 12/02/2016]

Drugbank. (2016c). The drugbank database. Estradiol. Available: https://www.drugbank.ca/ drugs/DB00783 [visited at 12/02/2016]

Drugbank. (2016d). The drugbank database. Ethinyl Estradiol. Available: https://www.drugbank.ca/drugs/DB00977 [visited at 12/02/2016]

Escolà Casas, M., Chhetri, R. K., Ooi, G., Hansen, K. M. S., Litty, K., Christensson, M., ... Bester, K. (2015). Biodegradation of pharmaceuticals in hospital wastewater by a hybrid biofilm and activated sludge system (Hybas). Science of the Total Environment, 530-531, 383-392. doi:10.1016/j.scitotenv.2015.05.099

Estrada-Arriaga, E. B., Cortés-Muñoz, J. E., González-Herrera, A., Calderón-Mólgora, C. G., Rivera-Huerta, M., de, L., Ramírez-Camperos, E., ... García-Sánchez, L. (2016). Assessment of full-scale biological nutrient removal systems upgraded with physicochemical processes for the removal of emerging pollutants present in wastewaters from 
Mexico. Science of the Total Environment, 571, 1172-1182. doi:10.1016/j.scitotenv.2016. 07.118

Falås, P., Longrée, P., La Cour Jansen, J., Siegrist, H., Hollender, J., \& Joss, A. (2013). Micropollutant removal by attached and suspended growth in a hybrid biofilm-activated sludge process. Water Research, 47(13), 4498-4506. doi:10.1016/j.watres.2013.05.010

Fenet, H., Mathieu, O., Mahjoub, O., Li, Z., Hillaire-Buys, D., Casellas, C., \& Gomez, E. (2012). Carbamazepine, carbamazepine epoxide and dihydroxycarbamazepine sorption to soil and occurrence in a wastewater reuse site in Tunisia. Chemosphere, 88(1), 49-54. doi:10.1016/j.chemosphere.2012.02.050

Fent, K., Weston, A. A., \& Caminada, D. (2006). Ecotoxicology of human pharmaceuticals. Aquatic Toxicology (Amsterdam, Netherlands), 76(2), 122-159. doi:10.1016/j.aquatox. 2005.09.009

Ferrari, B., Paxéus, N., Lo Giudice, R., Pollio, A., \& Garric, J. (2003). Ecotoxicological impact of pharmaceuticals found in treated wastewaters: Study of carbamazepine, clofibric acid, and diclofenac. Ecotoxicology and Environmental Safety, 55(3), 359-70.

Foolad, M., Hu, J., Tran, N. H., \& Ong, S. L. (2016). Sorption and biodegradation characteristics of the selected pharmaceuticals and personal care products onto tropical soil. Water Science and Technology, 73(1), 51-59. doi:10.2166/wst.2015.461

Gao, P., Mao, D., Luo, Y., Wang, L., Xu, B., \& Xu, L. (2012). Occurrence of sulfonamide and tetracycline-resistant bacteria and resistance genes in aquaculture environment. Water Research, 46(7), 2355-2364. doi:10.1016/j.watres.2012.02.004

Geissen, V., Mol, H., Klumpp, E., Umlauf, G., Nadal, M., Vander Ploeg, M., ... Ritsema, C. J. (2015). Emerging pollutants in the environment: A challenge for water resource management. International Soil and Water Conservation Research, 3(1), 57-65. doi:10. 1016/j.iswcr.2015.03.002

Göbel, A., McArdell, C. S., Joss, A., Siegrist, H., \& Giger, W. (2007). Fate of sulfonamides, macrolides, and trimethoprim in different wastewater treatment technologies. Science of the Total Environment, 372, 361-371. doi:10.1016/j.scitotenv.2006.07.039

Göbel, A., McArdell, C. S., Suter, M. J. F., \& Giger, W. (2004). Trace determination of macrolide and sulfonamide antimicrobials, a human sulfonamide metabolite, and trimethoprim in wastewater using liquid chromatography coupled to electrospray tandem mass spectrometry. Analytical Chemistry, 76, 4756-4764.

Göbel, A., Thomsen, A., McArdell, C. S., Joss, A., \& Giger, W. (2005). Occurrence and sorption behavior of sulfonamides, macrolides, and trimethoprim in activated sludge treatment. Environmental Science \& Technology, 39, (11), 3981-3989. doi:10.1021/ es048550a

Golan-Rozen, N., Chefetz, B., Ben-Ari, J., Geva, J., \& Hadar, Y. (2011). Transformation of the recalcitrant pharmaceutical compound carbamazepine by pleurotus ostreatus: Role of cytochrome P450 monooxygenase and manganese peroxidase. Environmental Science of Technology, 45(16), 6800-6805. doi:10.1021/es200298t [InsetedFromOnline]

Goldstein, M., Shenker, M., \& Chefetz, B. (2014). Insights into the uptake processes of wastewater-borne pharmaceuticals by vegetables. Environmental Science \& Technology, 48(10), 5593-5600. doi:10.1021/es5008615

Gray, L. E. Jr., (1998). Xenoendocrine disrupters: Laboratory studies on male reproductive effects. Toxicology Letters, 102-103, 331-335. doi:10.1016/S0378-4274(98)00327-0

Grandclément, C., Seyssiecq, I., Piram, A., Wong-Wah-Chung, P., Vanot, G., Tiliacos, N., ... Doumenq, P. (2017). From the conventional biological wastewater treatment to hybrid processes, the evaluation of organic micropollutant removal: A review. Water Research, 111, 297-317. doi:10.1016/j.watres.2017.01.005 
Gros, M., Petrović, M., Ginebreda, A., \& Barceló, D. (2010). Removal of pharmaceuticals during wastewater treatment and environmental risk assessment using hazard indexes. Environment International, 36(1), 15-26. doi:10.1016/j.envint.2009.09.002

Gross, B., Montgomery-Brown, J., Naumann, A., \& Reinhard, M. (2004). Occurrence and fate of pharmaceuticals and alkylphenol ethoxylate metabolites in an effluent-dominated river and wetland. Environmental Toxicology and Chemistry, 23(9), 2074-2083. doi:10. 1897/03-606

Guo, X., Pang, W., Dou, C., \& Yin, D. (2017). Sulfamethoxazole and COD increase abundance of sulfonamide resistance genes and change bacterial community structures within sequencing batch reactors. Chemosphere, 175, 21-27. doi:10.1016/j.chemosphere.2017.01. 134

Hamscher, G., Pawelzick, H. T., Sczesny, S., Nau, H., \& Hartung, J. (2003). Antibiotics in dust originating from a pig fattening farm: A new source of health hazard for farmers?. Environmental Health Perspectives, 111(13), 1590-1594. doi:10.1289/ehp.6288

Hashimoto, T., \& Murakami, T. (2009). Removal and degradation characteristics of natural and synthetic estrogens by activated sludge in batch experiments. Water Research, 43(3), 573-582. doi:10.1016/j.watres.2008.10.051

Heberer, T., Reddersen, K., \& Mechlinski, A. (2002). From municipal sewage to drinking water: Fate and removal of pharmaceutical residues in the aquatic environment in urban areas. Water Science and Technology, 46(3), 81-88. doi:10.2166/wst.2002.0060

Heye, K., Becker, D., Eversloh, C. L., Durmaz, V., Ternes, T. A., Oetken, M., \& Oehlmann, J. (2016). Effects of carbamazepine and two of its metabolites on the non-biting midge Chironomus riparius in a sediment full life cycle toxicity test. Water Research, 98, 19-27. doi:10.1016/j.watres.2016.03.071

Hijosa-Valsero, M., Matamoros, V., Martín-Villacorta, J., Bécares, E., \& Bayona, J. M. (2010). Assessment of full-scale natural systems for the removal of PPCPs from wastewater in small communities. Water Research, 44(5), 1429-1439. doi:10.1016/j.watres. 2009.10.032

Hirsch, R., Ternes, T., Haberer, K., \& Kratz, K. L. (1999). Occurrence of antibiotics in the aquatic environment. Science of the Total Environment, 225(1-2), 109-118.

Hjorth, N., \& Roed-Petersen, J. (1980). Allergic contact dermatitis in veterinary surgeons. Contact Dermatitis, 6(1), 27-29. doi:10.1111/j.1600-0536.1980.tb03885.x

Hruska, K., \& Franek, M. (2012). Sulfonamides in the environment: A review and a case report. Veterinární Medicína, 57(1), 1-35. doi:10.17221/4969-VETMED

Huang, Q., Bu, Q., Zhong, W., Shi, K., Cao, Z., \& Yu, G. (2018). Derivation of aquatic predicted no-effect concentration (PNEC) for ibuprofen and sulfamethoxazole based on various toxicity endpoints and the associated risks. Chemosphere, 193, 223-229. doi:10. 1016/j.chemosphere.2017.11.029

Hyland, K. C., Dickenson, E. R. V., Drewes, J. E., \& Higgins, C. P. (2012). Sorption of ionized and neutral emerging trace organic compounds onto activated sludge from different wastewater treatment configurations. Water Research, 46(6), 1958-1968. doi:10.1016/j. watres.2012.01.012

INCHEM. (2016). - International program on chemical safety. Carbamazepine. Available: http://www.inchem.org/documents/pims/pharm/pim100.htm [visited at 12/02/2016]

IWW. (2014). Pharmaceuticals in the environment: Occurrence, effects, and options for action. Research project funded by the German Federal Environment Agency (UBA) within the Environmental Research Plan No. 371265 408. http://www.pharmaceuticalsin-the-environment.org. 
Jelic, A., Cruz-Morató, C., Marco-Urrea, E., Sarrà, M., Perez, S., Vicent, T., ... Barcelo, D. (2012). Degradation of carbamazepine by Trametes versicolor in an air pulsed fluidized bed bioreactor and identification of intermediates. Water Research, 46(4), 955-964. doi: 10.1016/j.watres.2011.11.063

de Jesus Gaffney, V., Cardoso, V. V., Cardoso, E., Teixeira, A. P., Martins, J., Benoliel, M. J., \& Almeida, C. M. M. (2017). Occurrence and behaviour of pharmaceutical compounds in a Portuguese wastewater treatment plant: Removal efficiency through conventional treatment processes. Environmental Science and Pollution Research, 24(17), 14717-14734. doi:10.1007/s11356-017-9012-7

Ji, C., Hou, J., Wang, K., Zhang, Y., \& Chen, V. (2016). Biocatalytic degradation of carbamazepine with immobilized laccase-mediator membrane hybrid reactor. Journal of Membrane Science, 502, 11-20. doi:10.1016/j.memsci.2015.12.043

Johnson, A. C., Aerni, H.-R., Gerritsen, A., Gibert, M., Giger, W., Hyllan, K., ... Wettstein, F. E. (2005). Comparing steroid estrogen, and nonylphenol content across a range of European sewage plants with different treatment and management practices. Water Research, 39(1), 47-58. doi:10.1016/j.watres.2004.07.025

Johnson, A. C., Belfroid, A., \& Di Corcia, A. (2000). Estimating steroid oestrogen inputs into activated sludge treatment works and observations on their removal from the effluent. Science of the Total Environment, 256(2-3), 163-173. doi:10.1016/S00489697(00)00481-2

Johnson, A. C., \& Sumpter, J. P. (2001). Removal of endocrine-disrupting chemicals in activated sludge treatment works. Environmental Science \& Technology, 35(24), 4697-4703. doi:10.1021/es010171j

Johnson, A. C., \& Williams, R. J. (2004). A model to estimate influent and effluent concentrations of estradiol sewage treatment works. Environmental Science \& Technology, 38(13), 3649-3658. doi:10.1021/es035342u

Jones, O. A. H., Voulvoulis, N., \& Lester, J. N. (2002). Aquatic environmental assessment of the top 25 English prescription pharmaceuticals. Water Research, 36(20), 5013-5022. doi:10.1016/S0043-1354(02)00227-0

Jos, A., Repetto, G., Rios, J. C., Hazen, M. J., Molero, M. L., del Peso, A., ... Cameán, A. (2003). Ecotoxicological evaluation of carbamazepine using six different model systems with eighteen endpoints. Toxicology in Vitro, 17(5-6), 525-532. doi:10.1016/S08872333(03)00119-X

Joss, A., Zabczynski, S., Göbel, A., Hoffmann, B., Loffler, D., Mcardell, C. S., ... Siegrist, H. (2006). Biological degradation of pharmaceuticals in municipal wastewater treatment: Proposing a classification scheme. Water Research, 40(8), 1686-1696. doi:10.1016/j. watres.2006.02.014

Joss, A., Andersen, H., Ternes, T., Richle, P. R., \& Siegrist, H. (2004). Removal of estrogens in municipal wastewater treatment under aerobic and anaerobic conditions: Consequences for plant optimization. Environmental Science \& Technology, 38(11), 3047-3055. doi:10.1021/es0351488

Ju, C., \& Uetrecht, J. P. (1999). Detection of 2-hydroxyiminostilbene in the urine of patients taking carbamazepine and its oxidation to a reactive iminoquinone intermediate. Journal of Pharmacology and Experimental Therapeutics, 288, 51-56.

Kidd, K. A., Blanchfield, P. J., Mills, K. H., Palace, V. P., Evans, R. E., Lazorchak, J. M., \& Flick, R. W. (2007). Collapse of a fish population after exposure to a synthetic estrogen. Proceedings of the National Academy of Sciences of the United States of America, 104(21), 8897-8901. doi:10.1073/pnas.0609568104 
Kim, M., Guerra, P., Shah, A., Parsa, M., Alaee, M., \& Smyth, S. A. (2014). Removal of pharmaceuticals and personal care products in a membrane bioreactor wastewater treatment plant. Water Science and Technology, 69(11), 2221-2229. doi:10.2166/wst.2014.145

Kim, S. D., Cho, J., Kim, I. S., Vanderford, B. J., \& Snyder, S. A. (2007). Occurrence and removal of pharmaceuticals and endocrine disruptors in South Korean surface, drinking, and waste waters. Water Research, 41(5), 1013-1021. doi:10.1016/j.watres.2006.06.034

Kimura, K., Hara, H., \& Watanabe, Y. (2007). Elimination of selected acidic pharmaceuticals from municipal wastewater by an activated sludge system and membrane bioreactors. Environmental Science \& Technology, 41(10), 3708-3714. doi:10.1021/es061684z

Klein, E. Y., Van Boeckel, T. P., Martinez, E. M., Pant, S., Gandra, S., Levin, S. A., ... Laxminarayan, R. (2018). Global increase and geographic convergence in antibiotic consumption between 2000 and 2015. Proceedings of the National Academy of Sciences, 115(15), E3463-E3470. doi:10.1073/pnas.1717295115

Koczura, R., Mokracka, J., Taraszewska, A., \& Łopacinska, N. (2016). Abundance of Class 1 integron-integrase and sulfonamide resistance genes in river water and sediment is affected by anthropogenic pressure and environmental factors. Microbial Ecology, 72(4), 909-916. doi:10.1007/s00248-016-0843-4

Koh, Y. K. K., Chiu, T. W., Boobis, A. R., Scrimshaw, M. D., Bagnall, J. P., Soares, A., Pollard, S., Lester, E. ... (2009). Influence of operating parameters on the biodegradation of steroid estrogens and nonylphenolic compounds during biological wastewater treatment processes. Environmental Science \& Technology, 43(17), 6646-6654. doi:10. $1021 / \mathrm{es} 901612 \mathrm{v}$

Kolpin, D., Furlong, E., Meyer, M., Thurman, E. M., Zaugg, S., Barber, L., \& Buxton, H. (2002) Pharmaceuticals, hormones, and other organic wastewater contaminants in U.S. Streams, 1999-2000: A National Reconnaissance USGS Staff - Published Research. 68.

Kolodziej, E. P., Harter, T., \& Sedlak, D. L. (2004). Dairy wastewater, aquaculture, and spawning fish as sources of steroid hormones in the aquatic environment. Environmental Science \& Technology, 38(23), 6377-6384. doi:10.1021/es049585d

Kruglova, A., Ahlgren, P., Korhonen, N., Rantanen, P., Mikola, A., \& Vahala, R. (2014). Biodegradation of ibuprofen, diclofenac and carbamazepine in nitrifying activated sludge under $12{ }^{\circ} \mathrm{C}$ temperature conditions. Science of the Total Environment, 499, 394-401. doi: 10.1016/j.scitotenv.2014.08.069

Kruglova, A., Gonzalez-Martinez, A., Matilda Kråkström, M., Mikola, A., \& Vahala, R. (2017). Bacterial diversity and population shifts driven by spotlight wastewater micropollutants in low-temperature highly nitrifying activated sludge. Science of the Total Environment, 605-606, 291-299. doi:10.1016/j.scitotenv.2017.06.191

Kümmerer, K. (2003). Significance of antibiotics in the environment. The Journal of Antimicrobial Chemotherapy, 52(1), 5-7. doi:10.1093/jac/dkg293

de la Torre, T., Alonso, E., Santos, J. L., Rodríguez, C., Gómez, M. A., \& Malfeito, J. J. (2015). Trace organics removal using three membrane bioreactor configurations: MBR, IFAS-MBR and MBMBR. Water Science and Technology, 71(5), 761-768. doi:10.2166/ wst.2015.028

Lamichhane, K., Garcia, S. N., Huggett, D. B., Deangelis, D. L., \& La Point, T. W. (2013). Chronic effects of carbamazepine on life-history strategies of Ceriodaphnia dubia in three successive generations. Archives of Environmental Contamination and Toxicology, 64(3), 427-438. doi:10.1007/s00244-012-9845-5

Laurenson, J. P., Bloom, R. A., Page, S., \& Sadrieh, N. (2014). Ethinyl estradiol and other human pharmaceutical estrogens in the aquatic environment: A review of recent risk assessment data. The AAPS Journal, 16(2), 299-310. doi:10.1208/s12248-014-9561-3 
Lee, E., Lee, S., Park, J., Kim, Y., \& Cho, J. (2013). Removal and transformation of pharmaceuticals in wastewater treatment plants and constructed wetlands. Drinking Water Engineering and Science, 6(2), 89-98. doi:10.5194/dwes-6-89-2013

Leung, H. W., Jin, L., Wei, S., Tsui, M. M. P., Zhou, B., Jiao, L., ... Lam, P. K. S. (2013). Pharmaceuticals in tap water: human health risk assessment and proposed monitoring framework in China. Environmental Health Perspectives, 121(7), 839-846. doi:10.1289/ ehp. 1206244

Li, B., \& Zhang, T. (2010). Biodegradation and adsorption of antibiotics in the activated sludge process. Environmental Science \&Amp; Technology, 44(9), 3468-3473. doi:10.1021/ es $903490 \mathrm{~h}$

Li, F., Yuasa, A., Obara, A., \& Mathews, A. P. (2005). Aerobic batch degradation of 17- $\beta$ estradiol (E2) by activated sludge: Effects of spiking E2 concentrations, MLVSS and temperatures. Water Research, 39(10), 2065-2075. doi:10.1016/j.watres.2005.02.009

Lin, T., Chen, Y., \& Chen, W. (2013). Impact of toxicological properties of sulfonamides on the growth of zebrafish embryos in the water. Environmental Toxicology and Pharmacology, 36(3), 1068-1076. doi:10.1016/j.etap.2013.09.009

Lipman, A. G. (1993). Martindale - the Extra Pharmacopoeia (30th ed). Eds: Reynolds, JEF. London: The Pharmaceutical Press.

Liu, Z.-H., Lu, G.-N., Yin, H., Dang, Z., \& Rittmann, B. (2015). Removal of natural estrogens and their conjugates in municipal wastewater treatment plants: A critical review. Environmental Science \& Technology, 49(9), 5288-5300. doi:10.1021/acs.est.5b00399

Liu, F., Ying, G.-G., Tao, R., Zhao, J.-L., Yang, J.-F., \& Zhao, L.-F. (2009). Effects of six selected antibiotics on plant growth and soil microbial and enzymatic activities. Environmental Pollution, 157(5), 1636-1642.

Loos, R., Locoro, G., Comero, S., Contini, S., Schwesig, D., Werres, F., ... Gawlik, B. M. (2010). Pan-European survey on the occurrence of selected polar organic persistent pollutants in ground water. Water Research, 44(14), 4115-4126. doi:10.1016/j.watres.2010.05. 032

Luo, Y., Guo, W., Ngo, H. H., Nghiem, L. D., Hai, F. I., Kang, J., ... Price, W. E. (2014). A review on the occurrence of micropollutants in the aquatic environment and their fate and removal during wastewater treatment. Science of the Total Environment, 473-474, 619-641. doi:10.1016/j.scitotenv.2013.12.065

Luo, Y., Jiang, Q., Ngo, H. H., Nghiem, L. D., Hai, F. I., Price, W. E., ... Guo, W. (2015). Evaluation of micropollutant removal and fouling reduction in a hybrid moving bed biofilm reactor-membrane bioreactor system. Bioresource Technology, 191, 355-359. doi:10. 1016/j.biortech.2015.05.073

Luo, Y., Guo, W., Ngo, H. H., Nghiem, L. D., Hai, F. I., Kang, J., ... Price, W. E. (2014). Removal and fate of micropollutants in a sponge-based moving bed bioreactor. Bioresource Technology, 159, 311-319. doi:10.1016/j.biortech.2014.02.107

Luo, Y., Mao, D., Rysz, M., Zhou, Q., Zhang, H., Xu, L., \& J. J. Alvarez, P. (2010). Trends in antibiotic resistance genes occurrence in the Haihe River. Environmental Science \& Technology, 44(19), 7220-7225. doi:10.1021/es100233w

Ma, L., \& Yates, S. R. (2018). Degradation and metabolite formation of 17ß-estradiol-3-glucuronide and 17ß-estradiol-3-sulphate in river water and sediment. Water Research, 139, 1-9. doi:10.1016/j.watres.2018.03.071

Madureira, T. V., Rocha, M. J., Cruzeiro, C., Rodrigues, I., Monteiro, R. A. F., \& Rocha, E. (2012). The toxicity potential of pharmaceuticals found in the Douro River estuary (Portugal): Evaluation of impacts on fish liver, by histopathology, stereology, vitellogenin 
and CYP1A immunohistochemistry, after sub-acute exposures of the zebrafish model. Environmental Toxicology and Pharmacology, 34(1), 34-45. doi:10.1016/j.etap.2012.02.007

Maeng, S. K., Choi, B. G., Lee, K. T., \& Song, K. G. (2013). Influences of solid retention time, nitrification and microbial activity on the attenuation of pharmaceuticals and estrogens in membrane bioreactors. Water Research, 47(9), 3151-3162. doi:10.1016/j.watres. 2013.03.014

Magurran, A. E. (2004). Measuring biological diversity. Oxford: Blackwell Publishing.

Majewsky, M., Wagner, D., Delay, M., Bräse, S., Yargeau, V., \& Horn, H. (2014). Antibacterial activity of sulfamethoxazole transformation products (TPs): General relevance for sulfonamide TPs modified at the para position. Chemical Research in Toxicology, 27(10), 1821-1828. doi:10.1021/tx500267x

Manickum, T., \& John, W. (2014). Occurrence, fate and environmental risk assessment of endocrine disrupting compounds at the wastewater treatment works in Pietermaritzburg (South Africa). Science of the Total Environment, 468-469, 584-597. doi:10.1016/j.scitotenv.2013.08.041

Martínez-Alcalà, I., Guillén-Navarro, J. M., \& Fernández-López, C. (2017). Pharmaceutical biological degradation, sorption and mass balance determination in a conventional activated-sludge wastewater treatment plant from Murcia. Spain. Chemical Engineering Journal, 316, 332-340. doi:10.1016/j.cej.2017.01.048

Martín, J., Camacho-Muñoz, D., Santos, J. L., Aparicio, I., \& Alonso, E. (2012). Occurrence of pharmaceutical compounds in wastewater and sludge from wastewater treatment plants: Removal and ecotoxicological impact of wastewater discharges and sludge disposal. Journal of Hazardous. Materials, 239-240, 40-47. doi:10.1016/j.jhazmat.2012.04.068

Martinez, J. L. (2008). Antibiotics and antibiotic resistance genes in natural environments. Science, 321(5887), 365-367. doi:10.1126/science.1159483

Matamoros, V., García, J., \& Bayona, J. M. (2008). Organic micropollutant removal in a full-scale surface flow constructed wetland fed with secondary effluent. Water Research, 42(3), 653-660. doi:10.1016/j.watres.2007.08.016

Matamoros, V., Rodríguez, Y., \& Albaigés, J. (2016). A comparative assessment of intensive and extensive wastewater treatment technologies for removing emerging contaminants in small communities. Water Research, 88, 777-785. doi:10.1016/j.watres.2015.10.058

Matejicek, D., Houserova, P., \& Kuban, V. (2007). Combined isolation and purification procedures prior to the high-performance liquid chromatographic-ion-trap tandem mass spectrometric determination of estrogens and their conjugates in river sediments. Journal of Chromatography A, 1171, 80-89.

McAdam, E. J., Bagnall, J. P., Koh, Y. K. K., Chiu, T. Y., Pollard, S., Scrimshaw, M. D., ... Cartmell, E. (2010). Removal of steroid estrogens in carbonaceous and nitrifying activated sludge processes. Chemosphere, 81(1), 1-6. doi:10.1016/j.chemosphere.2010.07.057

McAvoy, K. (2008). Occurrence of estrogen in wastewater treatment plant and waste disposal site water samples. Clearwaters: Contaminants of Emerging Concern, 38, 28-34.

Metcalfe, C. D., Koenig, B. G., Bennie, D. T., Servos, M., Ternes, T. A., \& Hirsch, R. (2003). Occurrence of neutral and acidic drugs in the effluents of Canadian sewage treatment plants. Environmental Toxicology and Chemistry, 22(12), 2872-2880. doi:10.1897/ 02-469

Metcalfe, C. D., Miao, X. S., Koenig, B. G., \& Struger, J. (2003). Distribution of acidic and neutral drugs in surface waters near sewage treatment plants in the lower Great Lakes. Environmental Toxicology and Chemistry, 22(12), 2881-2889. doi:10.1897/02-627 
Miao, X. S., \& Metcalfe, C. D. (2003). Determination of carbamazepine and its metabolites in aqueous samples using liquid chromatography-electrospray tandem mass spectrometry. Analytical Chemistry, 75(15), 3731-3738. doi:10.1021/ac030082k

Michael, I., Rizzo, L., McArdell, C. S., Manaia, C. M., Merlin, C., Schwartz, T., ... FattaKassinos, D. (2013). Urban wastewater treatment plants as hotspots for the release of antibiotics in the environment: A review. Water Research, 47(3), 957-995. doi:10.1016/j. watres.2012.11.027

Miège, C., Choubert, J. M., Ribeiro, L., Eusèbe, M., \& Coquery, M. (2009). Fate of pharmaceuticals and personal care products in wastewater treatment plants - Conception of a database and first results. Environmental Pollution, 157(5), 1721-1726. doi:10.1016/j.envpol.2008.11.045

Mohapatra, D. P., Brar, S. K., Tyagi, R. D., Picard, P., \& Surampalli, R. Y. (2014). Analysis and advanced oxidation treatment of a persistent pharmaceutical compound in wastewater and wastewater sludge-carbamazepine. Science of the Total Environment, 470-471, 58-75. doi:10.1016/j.scitotenv.2013.09.034

Mückter, H. (2006). Antibiotika-Rückstände im Trinkwasser. 47. Arbeitstagung des Arbeitsgebiets Lebensmittelhygiene, Garmisch-Partenkirchen.

Mugdal, S., De Toni, A., Lockwood, S., Salès, K., Backhaus, T., \& Sorensen, B. H. (2013). Study on the environmental risks of medicinal products. Final Report prepared by BIO Intelligent Service for Executive Agency for Health and Consumers.

Muter, O., P\Erkons, I., Selga, T., Berzins, A., Gudra, D., Radovica-Spalvina, I., ... Bartkevics, V. (2017). Removal of pharmaceuticals from municipal wastewaters at laboratory scale by treatment with activated sludge and biostimulation. Science of the Total Environment, 584-585, 402-413. doi:10.1016/j.scitotenv.2017.01.023

Nakada, N., Yasojima, M., Okayasu, Y., Komori, K., Tanaka, H., \& Suzuki, Y. (2006). Fate of oestrogenic compounds and identification of oestrogenicity in a wastewater treatment process. Water Science and Technology, 53(11), 51-63. doi:10.2166/wst.2006.337

National Center for Biotechnology Information. "National Center for Biotechnology Information. PubChem Compound Database; CID = 5329, https://pubchem.ncbi.nlm. nih.gov/compound/5329 (accessed May 23, 2017).

Navon, R., Hernandez-Ruiz, S., Chorover, J., \& Chefetz, B. (2011). Interactions of carbamazepine in soil: Effects of dissolved organic matter. Journal of Environmental Quality, 40(3), 942-948. doi:10.2134/jeq2010.0446

Nentwig, J., Oetken, M., \& Oehlmann, J. (2004). Effects of pharmaceuticals on aquatic invertebrates - the example of carbamazepine and clofibric acid. In Pharmaceuticals in the environment. source, fate, effects and risks (pp. 195-208). Berlin, Heidelberg: Springer-Verlag.

Nguyen, L. N., Hai, F. I., Dosseto, A., Richardson, C., Price, W. E., \& Nghiem, L. D. (2016). Continuous adsorption and biotransformation of micropollutants by granular activated carbon-bound laccase in a packed-bed enzyme reactor. Bioresource Technology, 210, 108-116. doi:10.1016/j.biortech.2016.01.014

Nguyen, L. N., Hai, F. I., Price, W. E., Kang, J., Leusch, F. D. L., Roddick, F., ... Nghiem, L. D. (2015). Degradation of a broad spectrum of trace organic contaminants by an enzymatic membrane reactor: Complementary role of membrane retention and enzymatic degradation. International Biodeterioration \& Biodegradation, 99, 115-122. doi:10. 1016/j.ibiod.2014.12.004

Nguyen, L. N., Hai, F. I., Kang, J., Price, W. E., \& Nghiem, L. D. (2013). Removal of emerging trace organic contaminants by MBR-based hybrid treatment processes. 
International Biodeterioration \& Biodegradation, 85, 474-482. doi:10.1016/j.ibiod.2013.03. 014

Nguyen, L. N., Hai, F. I., Price, W. E., Leusch, F. D. L., Roddick, F., Ngo, H. H., ... Nghiem, L. D. (2014). The effects of mediator and granular activated carbon addition on degradation of trace organic contaminants by an enzymatic membrane reactor. Bioresource Technology, 167, 169-177. doi:10.1016/j.biortech.2014.05.125

Novo, A., André, S., Viana, P., Nunes, O. C., \& Manaia, C. M. (2013). Antibiotic resistance, Antimicrobial residues and bacterial community composition in urban wastewater. Water Research, 47(5), 1875-1887. doi:10.1016/j.watres.2013.01.010

Odize, V., Rahman, A., Jones, K., Khunjar, W., \& Murthy, S. (2017). Removal of 17 $\alpha$-ethinylestradiol, salicylic acid, trimethoprim, carbamazepine and nonylphenol through biological carbon and nitrogen removal processes. Water and Environment Journal, 31(3), 440-449.

Osorio, V., Sanchís, J., Abad, J. L., Ginebreda, A., Farré, M., Pérez, S., \& Barceló, D. (2016). Investigating the formation and toxicity of nitrogen transformation products of diclofenac and sulfamethoxazole in wastewater treatment plants. Journal of Hazardous Materials, 309, 157-164. doi:10.1016/j.jhazmat.2016.02.013

Pal, A., Gin, K. Y.-H., Lin, A. Y.-C., \& Reinhard, M. (2010). Impacts of emerging organic contaminants on freshwater resources: Review of recent occurrences, sources, fate and effects. Science of the Total Environment, 408(24), 6062-6069. doi:10.1016/j.scitotenv. 2010.09.026

Panter, G. H., Thompson, R. S., Beresford, N., \& Sumpter, J. P. (1999). Transformation of a non-oestrogenic steroid metabolite to an oestrogenically active substance by minimal bacterial activity. Chemosphere, 38(15), 3579-3596. doi:10.1016/S0045-6535(98)00572-4

Pawlowski, S., Van Aerle, R., Tyler, C. R., \& Braunbeck, T. (2004). Effects of $17 \alpha$-ethinylestradiol in a fathead minnow (Pimephales promelas) gonadal recrudescence assay. Ecotoxicology and Environmental Safety, 57(3), 330-345. doi:10.1016/j.ecoenv.2003.07.019

Paz, A., Tadmor, G., Malchi, T., Blotevogel, J., Borch, T., Polubesova, T., \& Chefetz, B. (2016). Fate of carbamazepine, its metabolites, and lamotrigine in soils irrigated with reclaimed wastewater: Sorption, leaching and plant uptake. Chemosphere, 160, 22-29. doi:10.1016/j.chemosphere.2016.06.048

Pérez, S., Eichhorn, P., \& Aga, D. S. (2005). Evaluating the biodegradability of sulfamethazine, sulfamethoxazole, sulfathiazole, and trimethoprim at different stages of sewage treatment. Environmental Toxicology and Chemistry, 24(6), 1361-1367. doi:10.1897/04211R.1

Petrie, B., McAdam, E. J., Hassard, F., Stephenson, T., Lester, J. N., \& Cartmell, E. (2014). Diagnostic investigation of steroid estrogen removal by activated sludge at varying solids retention time. Chemosphere, 113, 101-108. doi:10.1016/j.chemosphere.2014.04.051

Petrie, B., Barden, R., \& Kasprzyk-Hordern, B. (2015). A review on emerging contaminants in wastewaters and the environment: Current knowledge, understudied areas and recommendations for future monitoring. Water Research, 72, 3-27. doi:10.1016/j.watres.2014. 08.053

Pholcan, M. K., Baptista, J. D C., Davenport, R. J., Sloan, W. T., \& Curtis, T. P. (2013). Microbial community assembly, theory and rare functions. Frontiers in Microbiology, 4, 68. doi:10.3389/fmicb.2013.00068

Polesel, F., Andersen, H. R., Trapp, S., \& Plósz, B. G. (2016). Removal of antibiotics in biological wastewater treatment systems - A critical assessment using the Activated Sludge Modelling framework for Xenobiotics (ASM-X). Environmental Science \& Technology, 50(19), 10316-10334. doi:10.1021/acs.est.6b01899 
Pomati, F., Castiglioni, S., Zuccato, E., Fanelli, R., Vigetti, D., Rossetti, C., \& Calamari, D. (2006). Effects of a complex mixture of therapeutic drugs at environmental levels on human embryonic cells. Environmental Science \& Technology, 40(7), 2442-2447. doi:10. 1021/es051715a

Racz, L., \& Goel, R. K. (2010). Fate and removal of estrogens in municipal wastewater. Journal of Environmental Monitoring, 12(1), 58-70. doi:10.1039/b917298j

Radjenović, J., Petrovic, M., \& Barceló, D. (2007). Analysis of pharmaceuticals in wastewater and removal using a membrane bioreactor. Analytical and Bioanalytical Chemistry, 387(4), 1365-1377. doi:10.1007/s00216-006-0883-6

Radjenović, J., Petrović, M., \& Barceló, D. (2009). Fate and distribution of pharmaceuticals in wastewater and sewage sludge of the conventional activated sludge (CAS) and advanced membrane bioreactor (MBR) treatment. Water Research, 43(3), 831-841. doi: 10.1016/j.watres.2008.11.043

Radke, M., Lauwigi, C., Heinkele, G., MüRdter, T. E., \& Letzel, M. (2009). Fate of the antibiotic sulfamethoxazole and its two major human metabolites in a water sediment test. Environmental Science \& Technology, 43(9), 3135-3141. doi:10.1021/es900300u

Rodarte-Morales, A. I., Feijoo, G., Moreira, M. T., \& Lema, J. M. (2011). Degradation of selected pharmaceutical and personal care products (PPCPs) by white-rot fungi. World Journal of Microbiology and Biotechnology, 27(8), 1839-1846. doi:10.1007/s11274-0100642-x

Rogers, H. R. (1996). Sources, behaviour and fate of organic contaminants during sewage treatment and in sewage sludges. Science of the Total Environment, 185(1-3), 3-26. doi: 10.1016/0048-9697(96)05039-5

RxList. (2016a). The Internet Drug Index. Tegretol (carbamazepine). Available: https://www. rxlist.com/tegretol-drug.htm [visited at 12/02/2016]

RxList. (2016b). The Internet Drug Index. Gantanol (sulfamethoxazole). Available: https:// www.rxlist.com/gantanol-drug.htm [visited at 12/02/2016]

Sacher, F., Lange, F. T., Brauch, H.-J., \& Blankenhorn, I. (2001). Pharmaceuticals in groundwaters: Analytical methods and resultsof a monitoring program in Baden Wurttemberg, Germany. Journal of Chromatography A, 938(1/2), 199-210. doi:10.1016/ S0021-9673(01)01266-3

Salgado, R., Marques, R., Noronha, J. P., Carvalho, G., Oehmen, A., \& Reis, M. A. M. (2012). Assessing the removal of pharmaceuticals and personal care products in a fullscale activated sludge plant. Environmental Science and Pollution Research, 19(5), 1818-1827. doi:10.1007/s11356-011-0693-Z

Sarmah, A. K., Meyer, M. T., \& Boxall, A. B. A. (2006). A global perspective on the use, sales, exposure pathways, occurrence, fate and effects of veterinary antibiotics (VAs) in the environment. Chemosphere, 65(5), 725-759. doi:10.1016/j.chemosphere.2006.03.026

Sarmah, A. K., Northcott, G. L., Leusch, F. D. L., \& Tremblay, L. A. (2006). A survey of endocrine disrupting chemicals (EDCs) in municipal sewage and animal waste effluents in the Waikato region of New Zealand. Science of the Total Environment, 355(1-3), 135-144. doi:10.1016/j.scitotenv.2005.02.027

Schröder, H. F., Tambosi, J. L., Sena, R. F., Moreira, R. F. P. M., José, H. J., \& Pinnekamp, J. (2012). The removal and degradation of pharmaceutical compounds during membrane bioreactor treatment. Water Science and Technology, 65(5), 833-839. doi:10.2166/wst. 2012.828

Seki, M., Fujishima, S., Nozaka, T., Maeda, M., \& Kobayashi, K. (2006). Comparison of response to 17 beta-estradiol and 17 beta-trenbolone among three small fish species. Environmental Toxicology and Chemistry, 25(10), 2742-2752. doi:10.1897/05-647R.1 
Sodré, F., Locatelli, M., Montagner, C., \& Jardim, W. (2007). Origem e destino de interferentes endócrinos em águas naturais. Caderno Temático: Universidade Estadual de Campinas, Campinas.

Solomon, G. M., \& Schettler, T. (2000). Environment and health: Endocrine disruption and potential human health implications. Canadian Medical Association Journal, 163(11), 1471-1476.

Soto, A. M., Justicia, H., Wray, J. W., \& Sonnenschein, C. (1991). p-Nonyl-phenol: An estrogenic xenobiotic released from modified polystyrene. Environmental Health Perspectives, 92, 167-173. doi:10.1289/ehp.9192167

Stein, K., Ramil, M., Fink, G., Sander, M., \& Ternes, T. A. (2008). Analysis and sorption of psychoactive drugs onto sediment. Environmental Science \& Technology, 42, (17), 6415-6423.

Stevens-Garmon, J., Drewes, J. E., Khan, S. J., McDonald, J. A., \& Dickenson, E. R. V. (2011). Sorption of emerging trace organic compounds onto wastewater sludge solids. Water Research, 45(11), 3417-3426. doi:10.1016/j.watres.2011.03.056

Straub, J. O. (2016). Aquatic environmental risk assessment for human use of the old antibiotic sulfamethoxazole in Europe. Environmental Toxicology and Chemistry, 35(4), 767-779. doi:10.1002/etc. 2945

Stumpe, B., \& Marschner, B. (2009). Factors controlling the biodegradation of $17 \beta$-estradiol, estrone and $17 \alpha$-ethinylestradiol in different natural soils. Chemosphere, 74(4), 556-562. doi:10.1016/j.chemosphere.2008.09.072

Stumpe, B., \& Marschner, B. (2007). Long-term sewage sludge application and wastewater irrigation on the mineralization and sorption of $17 \beta$-estradiol and testosterone in soils. Science of the Total Environment, 374(2-3), 282-291. doi:10.1016/j.scitotenv.2006.12.025

Suárez, S., Reif, R., Lema, J. M., \& Omil, F. (2012). Mass balance of pharmaceutical and personal care products in a pilot-scale single-sludge system: Influence of T, SRT and recirculation ratio. Chemosphere, $89(2), 164-171$. doi:10.1016/j.chemosphere.2012.05.094

Suárez, S., Lema, J. M., \& Omil, F. (2010). Removal of Pharmaceutical and Personal Care Products (PPCPs) under nitrifying and denitrifying conditions. Water Research, 44, 3214-3224. doi:10.1016/j.watres.2010.02.040

Suzuki, K., Hirai, H., Murata, H., \& Nishida, T. (2003). Removal of estrogenic activities of 17beta-estradiol and ethinylestradiol by ligninolytic enzymes from white rot fungi . Water Research, 37(8), 1972-1975. doi:10.1016/S0043-1354(02)00533-X

Suzuki, Y., \& Maruyama, T. (2006). Fate of natural estrogens in batch mixing experiments using municipal sewage and activated sludge. Water Research, 40(5), 1061-1069. doi:10. 1016/j.watres.2005.12.043

Svenson, A., Allard, A. S., \& Ek, M. (2003). Removal of estrogenicity in Swedish municipal sewage treatment plants. Water Research, 37(18), 4433-4443. doi:10.1016/S00431354(03)00395-6

Swan, S. H., Liu, F., Overstreet, J. W., Brazil, C., \& Skakkebaek, N. E. (2007). Semen quality of fertile US males in relation to their mothers' beef consumption during pregnancy. Human Reproduction, 22(6), 1497-1502. doi:10.1093/humrep/dem068

Tadkaew, N., Sivakumar, M., Khan, S. J., McDonald, J. A., \& Nghiem, L. D. (2010). Effect of mixed liquor $\mathrm{pH}$ on the removal of trace organic contaminants in a membrane bioreactor. Bioresource Technology, 101(5), 1494-1500. doi:10.1016/j.biortech.2009.09.082

Tambosi, J. L., de Sena, R. F., Favier, M., Gebhardt, W., José, H. J., Schröder, H. F., and ... de, F. M. P. (2010). Removal of pharmaceutical compounds in membrane bioreactors (MBR) applying submerged membranes. Desalination, 261(1-2), 148-156. doi:10.1016/j. desal.2010.05.014 
Tang, K., Ooi, G. T. H., Litty, K., Sundmark, K., Kaarsholm, K. M. S., Sund, C., ... Andersen, H. R. (2017). Removal of pharmaceuticals in conventionally treated wastewater by a polishing moving bed biofilm reactor (MBBR) with intermittent feeding. Bioresource Technology, 236, 77-86. doi:10.1016/j.biortech.2017.03.159

Temes, T. A., Andersen, H., Gilberg, D., \& Bonerz, M. (2002). Determination of estrogens in sludge and sediments by liquid extraction and GC/MS/MS. Analytical Chemistry, 74(14), 3498-3504.

Ternes, T. A. (1998). Occurrence of drugs in German sewage treatment plants and rivers. Water Research, 32(11), 3245-3260. doi:10.1016/S0043-1354(98)00099-2

Ternes, T. A., Stumpf, M., Mueller, J., Haberer, K., Wilken, R. D., \& Servos, M. (1999). Behavior and occurrence of estrogens in municipal sewage treatment plants - I. Investigations in Germany, Canada and Brazil. Science of the Total Environment, 225(1-2), 81-90. doi:10.1016/S0048-9697(98)00334-9

Ternes, T. A., Kreckel, P., \& Mueller, J. (1999). Behaviour andoccurrence of estrogens in municipal sewage treatment plants-II. Aerobic batch experiments with activated sludge. Science of the Total Environment, 225(1-2), 91-99. doi:10.1016/S0048-9697(98)00335-0

Thill, A. E. (2005). Pharmaceutical data elude researchers. Environmental Science \& Technology, 39(19), 193A-194A.

Ting, Y. F., \& Praveena, S. M. (2017). Sources, mechanisms, and fate of steroid estrogens in wastewater treatment plants: A mini review. Environmental Monitoring and Assessment, 189(178), 2.

Tiwari, B., Sellamuthu, B., Ouarda, Y., Drogui, P., Tyagi, R. D., \& Buelna, G. (2017). Review on fate and mechanism of removal of pharmaceutical pollutants from wastewater using biological approach. Bioresource Technology, 224, 1-12. doi:10.1016/j.biortech.2016. 11.042

Topp, E., Monteiro, S. C., Beck, A., Coelho, B. B., Boxall, A. B. A., Duenk, P. W., ... Metcalfe, C. D. (2008). Runoff of pharmaceuticals and personal care products following application of biosolids to an agricultural field. Science of the Total Environment, 396(1), 52-59. doi:10.1016/j.scitotenv.2008.02.011

Toxnet. (2016). Toxicology Data Network. Carbamazepine. Available: https://toxnet.nlm. nih.gov/cgi-bin/sis/search/a?dbs+hsdb:@term+@DOCNO + 3019 [visited at 12/02/2016]

Toxnet. (2018). Toxicology Data Network. Sulfamethoxazole. Available https://toxnet.nlm. nih.gov/cgi- bin/sis/search/r?dbs + hsdb:@term+@rn+@rel + 723-46-6 [visited at 19/04/ 2018]

Tran, N. H., Urase, T., \& Kusakabe, O. (2010). Biodegradation characteristics of pharmaceutical substances by whole fungal culture trametes versicolor and its laccase. Journal of Water and Environment Technology, 8(2), 125-140. doi:10.2965/jwet.2010.125

Uslu, M. O., Jasim, S., Arvai, A., Bewtra, J., \& Biswas, N. (2013). A survey of occurrence and risk assessment of pharmaceutical substances in the Great Lakes Basin. Ozone: Science \& Engineering, 35, 249-262. doi:10.1080/01919512.2013.793595

Verbinnen, R. T., Nunes, G. S., \& Vieira, E. M. (2010). Determinação de hormonios estrógenos em água potável usando Clae-dad. Química Nova, 33(9), 1837-1842. doi:10. 1590/S0100-40422010000900003

Vilchèze, C., \& Jacobs, W. R. (2012). The combination of sulfamethoxazole, trimethoprim, and isoniazid or rifampin is bactericidal and prevents the emergence of drug resistance in Mycobacterium tuberculosis. Antimicrobial Agents and Chemotherapy, 56(10), 5142-5148. doi:10.1128/AAC.00832-12

Wang, J., Lin, H., Sun, W., Xia, Y., Ma, J., Fu, J., ... Quian, M. (2016). Variations in the fate and biological effects of sulfamethoxazole, norfloxacin and doxycycline in different 
vegetable-soil systems following manure application. Journal of Hazardous Materials, 304, 49-57. doi:10.1016/j.jhazmat.2015.10.038

Wang, L. Y., Tam, N. F. Y., \& Zhang, X. H. (2011). Assimilation of 17 -ethinylestradiol by sludge and its stress on microbial communities under aerobic and anaerobic conditions. Journal of Environmental Science and Health, Part A. Toxic/Hazardous Substances and Environmental Engineering, 46, 242-247. doi:10.1080/10934529.2011.535411

Wang, N., Guo, X., Xu, J., Hao, L., Kong, D., \& Gao, S. (2015). Sorption and transport of five sulfonamide antibiotics in agricultural soil and soil-manure systems. Journal of Environmental Science and Health. Part. B, Pesticides, Food Contaminants, and Agricultural Wastes, 50(1), 23-33. doi:10.1080/03601234.2015.965612

Wang, S., \& Gunsch, C. K. (2011). Effects of selected pharmaceutically active compounds on treatment performance in sequencing batch reactors mimicking wastewater treatment plants operations. Water Research, 45(11), 3398-3406. doi:10.1016/j.watres.2011.03.055

Wang, S., Holzem, R. M., \& Gunsch, C. K. (2008). Effects of pharmaceutically active compounds on a mixed microbial community originating from a municipal wastewater treatment plant. Environmental Science \& Technology, 42(4), 1091-1095. doi:10.1021/ es072026x

Waring, R. H., \& Harris, R. M. (2005) Endocrine disrupters: A human risk? Molecular and Cellular Endocrinology, 244, 2-9.

Watkinson, A. J., Murby, E. J., Kolpin, D. W., \& Costanzo, S. D. (2009). The occurrence of antibiotics in an urban watershed: From wastewater to drinking water. The Science of the Total Environment, 407(8), 2711-2723. doi:10.1016/j.scitotenv.2008.11.059

Watkinson, A. J., Murby, E. J., \& Costanzo, S. D. (2007). Removal of antibiotics in conventional and advanced wastewater treatment: Implications for environmental discharge and wastewater recycling. Water Research, 41(18), 4164-4176. doi:10.1016/j.watres.2007.04. 005

Wiegel, S., Aulinger, A., Brockmeyer, R., Harms, H., Loffler, J., Reincke, H., ... Wanke, A. (2004). Pharmaceuticals in the river Elbe and its tributaries. Chemosphere, 57(2), 107-126. doi:10.1016/j.chemosphere.2004.05.017

Wise, A., O'Brien, K., \& Woodruff, T. (2011). Are oral contraceptives a significant contributor to the estrogenicity of drinking water? Environmental Science \& Technology, 45(1), 51-60. doi:10.1021/es1014482

Wu, X., Conkle, J. L., Ernst, F., \& Gan, J. (2014). Treated wastewater irrigation: Uptake of pharmaceutical and personal care products by common vegetables under field conditions. Environmental Science \& Technology, 48(19), 11286-11293. doi:10.1021/es502868k

Xia, S., Jia, R., Feng, F., Xie, K., Li, H., Jing, D., \& Xu, X. (2012). Effect of solids retention time on antibiotics removal performance and microbial communities in an A/O-MBR process. Bioresource Technology, 106, 36-43. doi:10.1016/j.biortech.2011.11.112

Yan, Q., Gao, X., Chen, Y.-P., Peng, X.-Y., Zhang, Y.-X., Gan, X.-M., ... Guo, J.-S. (2014). Occurrence, fate and ecotoxicological assessment of pharmaceutically active compounds in wastewater and sludge from wastewater treatment plants in Chongqing, the Three Gorges Reservoir Area. Science of the Total Environment, 470-471, 618-630. doi:10.1016/ j.scitotenv.2013.09.032

Yang, S. F., Lin, C. F., Wu, C. J., Ng, K. K., Lin, A. Y., \& Hong, P. K. (2012). Fate of sulfonamide antibiotics in contact with activated sludge - Sorption and biodegradation. Water Research, 46(4), 1301-1308. doi:10.1016/j.watres.2011.12.035

Yergeau, E., Lawrence, J. R., Waiser, M. J., Korber, D. R., \& Greer, C. W. (2010). Metatranscriptomic analysis of the response of river biofilms to pharmaceutical products, 
using anonymous DNA microarrays. Applied and Environmental Microbiology, 76(16), 5432-5439. doi:10.1128/AEM.00873-10

Yergeau, E., Sanschagrin, S., Waiser, M. J., Lawrence, J. R., \& Greer, C. W. (2012). Subinhibitory concentrations of different pharmaceutical products affect the meta-transcriptome of river biofilm communities cultivated in rotating annular reactors. Environmental Microbiology Reports, 4(3), 350-359. doi:10.1111/j.1758-2229.2012.00341.x

Ying, G., Kookana, R. S., \& Kumar, A. (2008). Fate of estrogens and xenoestrogens in four sewage treatment plants with different technologies. Environmental Toxicology and Chemistry, 27(1), 87-94. doi:10.1897/07-046.1

Ying, G. G., Kookana, R. S., \& Ru, Y. J. (2002). Occurrence and fate of hormone steroids in the environment. Environment International, 28(6), 545-551.

Zhang, Y., \& Geissen, S.-U. (2010). In vitro degradation of carbamazepine and diclofenac by crude lignin peroxidase. Journal of Hazardous Materials, 176(1-3), 1089-1092. doi:10. 1016/j.jhazmat.2009.10.133

Zhang, Y., Geißen, S. U., \& Gal, C. (2008). Carbamazepine and diclofenac: Removal in wastewater treatment plants and occurrence in water bodies. Chemosphere, 73(8), 1151-1161. doi:10.1016/j.chemosphere.2008.07.086

Zhang, K., Zhao, Y., \& Fent, K. (2017). Occurrence and ecotoxicological effects of free, conjugated, and halogenated steroids including $17 \alpha$-hydroxypregnanolone and pregnanediol in Swiss wastewater and surface water. Environmental Science \& Technology, 51(11), 6498-6506. doi:10.1021/acs.est.7b01231

Zhou, Y., Zha, J., Xu, Y., Lei, B., \& Wang, Z. (2012). Occurrences of six steroid estrogens from different effluents in Beijing. Environmental Monitoring and Assessment, 184(3), 1719-1729. doi:10.1007/s10661-011-2073-Z

Zhu, Y., Wang, Y., Jiang, X., Zhou, S., Wu, M., Pan, M., \& Chen, H. (2017). Microbial community compositional analysis for membrane bioreactor treating antibiotics containing wastewater. Chemical Engineering Journal, 325, 300-309. doi:10.1016/j.cej.2017.05.073

Ziels, R. M., Lust, M. J., Gough, H. L., Strand, S. E., \& Stensel, H. D. (2014). Influence of bioselector processes on $17 \alpha$-ethinylestradiol biodegradation in activated sludge wastewater treatment systems. Environmental Science \& Technology, 48(11), 6160-6167. doi:10. $1021 / \mathrm{es} 405351 \mathrm{~b}$

Zuccato, E., Castiglioni, S., Bagnati, R., Melis, M., \& Fanelli, R. (2010). Source, occurrence and fate of antibiotics in the Italian aquatic environment. Journal of Hazardous Materials, 179(1-3), 1042-1048. doi:10.1016/j.jhazmat.2010.03.110 